\title{
Duff burning from wildfires in a moist region: different impacts on PM2.5 and Ozone
}

\author{
Aoxing Zhang ${ }^{1}$, Yongqiang Liu ${ }^{1}$, Scott Goodrick ${ }^{1}$, Marcus D Williams ${ }^{1}$ \\ ${ }^{1}$ Center for Forest Disturbance Science, US Forest Service, 320 Green St., Athens, 30602, United States \\ 5 Correspondence to: Yongqiang Liu (yongqiang.liu@usda.gov)
}

\begin{abstract}
Wildfires can significantly impact air quality and human health. However, little is known about how duff and peat burning contributes to these impacts. This study investigates the air quality impacts of duff consumption during the four largest wildfire events this century in southeastern United States, with a focus on the different impacts on fine particulate matter less than $2.5 \mu \mathrm{m}$ in size $\left(\mathrm{PM}_{2.5}\right)$ and ozone $\left(\mathrm{O}_{3}\right)$. The emissions of duff burning were estimated based on a field measurement. The

10 emissions from the burning of other fuels were obtained from the Fire INventory from NCAR (FINN). The air quality impacts were simulated using a 3-D regional air quality model. The results show the duff burning emitted $\mathrm{PM}_{2.5}$ comparable to the burning of the above-ground fuels. The simulated surface $\mathrm{PM}_{2.5}$ concentrations due to duff burning increased by $61.3 \%$ locally over a region approximately $300 \mathrm{~km}$ within the fire site and by $21.3 \%$ and $29.7 \%$ in the remote metro Atlanta and Charlotte during the 2016 southern Appalachian fires, and by 131.9\% locally and by 17.7\% and 24.8\% in the remote metro Orlando and

15 Miami during the 2007 Okefenokee fire. However, the simulated ozone impacts from the duff burning were negligible due to the small duff emission factors of ozone precursors such as $\mathrm{NO}_{\mathrm{x}}$. This study suggests the need to improve the modeling of $\mathrm{PM}_{2.5}$ and the air quality, human health, and climate impacts of wildfires in moist ecosystems by including duff burning in global fire emission inventories.
\end{abstract}

\section{Introduction}

Wildfires, caused by natural factors or human activities, have a fundamental impact on air quality, human health, and climate. Wildfires contribute up to $40 \%$ organic carbon (OC) emissions in Europe, $42 \%$ in Asia, $64 \%$ globally, and dominate the regional particular matters (PM) concentrations over the major fire regions in Africa and South America (Granier et al., 2011; Diehl et al., 2012). Fires contribute $26.9 \%$ of total volatile organic compounds (VOC) emissions and $27.5 \%$ of PM emissions 25 in the U.S. according to the 2014 US Environmental Protection Agency (EPA) National Emissions Inventory (NEI) (USEPA, 2017). Wildfires are large sources of atmospheric aerosols (Crutzen and Andreae, 1990; Bond et al., 2005; Bowman et al., 2009; Brey and Fischer, 2016), contributing 30\% of the aerosol optical thickness (AOT) in Europe (Hodzic et al., 2007), more than $80 \%$ in the Amazon area during the fire season (Reddington et al., 2019), and 10\% globally (Tosca et al., 2013). In the contiguous US during 2008 - 2012, fires contribute $11 \%$ of the total $\mathrm{PM}_{2.5}$ concentrations (Wilkins et al., 2018). 
Wildfires emit tracer gases including ozone precursors and therefore contribute to tropospheric ozone, a critical air pollution compound that adversely impacts human health (McKee, 1993). Ozone production has been detected in fire plumes (Goode et al., 2000; Jaffe et al., 2008). Wildfires produce about 3.5\% of global tropospheric ozone production, though ozone production rates of individual fires vary with fuel type, combustion efficiency, etc. (Alvarado et al., 2010; Jaffe and Wigder, 2012). In the United States, when fires are present, 14\% of simulated maximum daily 8-h average ozone concentrations surpassed $70 \mathrm{ppb}$ (Wilkins et al., 2018), which is the standard from EPA.

High-severity fire events have frequently impacted metropolitan regions. For example, the smoke from the 2013 Rim Fire and wildfires during 2017 and 2018 in California, US was transported long-range and affected large urban areas (Liu et al., 2016; Navarro et al., 2016; Mass and Ovens, 2019; Brown et al., 2020). The smoke from the 2009 Attica forest fires decreased the surface solar irradiance levels by 70\% in Athens, Greece (Amiridis et al., 2012). The 2017 Italian Alps fire had a significant impact on metro Torino, Italy (Bo et al., 2020). Similar fire events impacted urban air quality in other regions around the world (Shaposhnikov et al., 2014; Mallia et al., 2015; He et al., 2016; Cuchiara et al., 2017). In many regions around the world, including the U.S., wildfires have an increasing trend during recent decades (Yang et al., 2011; Dennison et al., 2014; Barbero et al., 2015; Jolly et al., 2015; Abatzoglou and Williams, 2016), leading to an increasing concern on their adverse impact on air quality (Singh et al., 2012; Goodrick et al., 2013; Liu et al., 2014; Zhang and Wang, 2016).

Negative impacts of wildfires on human health are devastating when fire plumes are transported to populated metropolitan 50 areas (Kunzli et al., 2006). Epidemiological studies have revealed fire emissions' contribution to $\mathrm{PM}_{2.5}$ oxidative potential, which is related to respiratory and cardiovascular diseases (Verma et al., 2014; Yang et al., 2016; Fang et al., 2016). Wildfires also interact with climate in terms of the atmospheric circulation, land cover change, terrestrial productivity, and radiative forcing (Tosca et al., 2013; Yue and Unger, 2018; Zou et al., 2020). Smoke aerosols have both positive and negative impacts on global radiative balance, depending on the absorbing and scattering contribution of aerosols, which contributes $40 \%$ of global radiative forcing uncertainties (IPCC, 2013).

Several datasets and three-dimensional atmospheric models have been used to understand the amount, transport, and physical and chemical processes of fire emissions (Liu et al., 2020; Pan et al., 2020). Some widely used global fire emission inventories include the Global Fire Emission Dataset (GFED) (Randerson et al., 2012; Giglio et al., 2013; Van Der Werf et al., 2017), Fire INventory from NCAR (FINN) (Wiedinmyer et al., 2006; Wiedinmyer et al., 2011), Global Fire Assimilation System (GFAS) (Kaiser et al., 2009; Kaiser et al., 2012), Fire Energetics and Emissions Research (FEER) (Ellison et al., 2014), and Quick Fire Emissions Dataset (QFED) (Darmenov and da Silva, 2013). Global atmospheric models such as the Community Earth System 
Model (CESM) were used to study wildfire smoke transport and interactions with land and atmosphere (Jiang et al., 2020;

Zhang et al., 2020; Zou et al., 2020) and the GEOS-Chem model was used to evaluate the wildfire contribution to atmospheric chemistry (Lu et al., 2016). Regional air quality models, such as the Weather Research and Forecasting model with Chemistry (WRF-Chem) and the Community Multiscale Air Quality (CMAQ) model have higher spatial resolutions, thus have advantages when simulating fire smoke aging and regional plume transport (Jaffe et al., 2008; Lu and Sokolik, 2017; San Jose et al., 2017; Wilkins et al., 2018; Guan et al., 2020).

Emissions from duff burns are an important contributor to the global carbon cycle. Duff typically represents the detritus or dead plant organic materials fallen at the top layer of soil. Temperate and boreal duff layers are well distributed in forests and swamps in North America, Europe and Asia (Wieder et al., 2006). Compared to the burning of above-ground fuel, duff burning can have a similar or larger amount of carbon emission, enlarging the regional and global effect from wildfires (Ballhorn et al., 2009; Reddy et al., 2015). The burning of the above-ground fuel and the below-ground organic soils may provoke each other in fire events (Rein, 2011). Ground-based studies have been conducted to estimate the carbon loss from temperate duff flaming or smoldering. Davies et al. (2013) surveyed the peatland smoldering in the Scottish Highlands, UK and estimated a $17.5 \pm 2.0 \mathrm{~cm}$ burned depth of below-ground fuel and $9.6 \pm 1.5 \mathrm{~kg} \mathrm{~m}^{-2}$ carbon loss due to smoldering. In North Carolina, US, the 1985 Pocosin Lakes fire resulted in a carbon flux of $0.2-11 \mathrm{~kg} \mathrm{~m}^{-2}$, that varies with burned depth, vegetation type and burning severity (Poulter et al., 2006). Assuming 50\% of the duff mass is carbon (Watts, 2013), this fuel loading results in a carbon loss of approximately $1.6 \mathrm{~kg} \mathrm{~m}^{-2}$. Watts (2013) estimated $4.18 \mathrm{~kg} \mathrm{~m}^{-2}$ carbon release from the swamp combustion in the Big Cypress National Preserve in southern Florida, US. Besides duff, peat is another burnable organic soil that typically represents the fermentation below the duff layer (Frandsen, 1987). Duff and peat are a major reservoir of swamp carbon and contribute 3\% of global land cover (Gorham, 1991; Yu et al., 2010). The burning properties and emission factors of the belowground organic soils, including duff and peat, are similar (Raaflaub and Valeo, 2009; Urbanski, 2014). The air quality impacts from peatland burning are also evaluated in tropical peatlands in Indonesia (Page et al., 2002; Kiely et al., 2020).

However, the air quality impacts of emissions from duff fires are very limited and not well understood (Page et al., 2002; Hu et al., 2018). One of the reasons is the lack of the fire emission data (Ward et al., 2012), which is a large uncertainty source for simulations of the fire impacts on air quality. Satellite remote sensing is a very useful tool to obtain fire emissions with detailed global and regional coverage. The organic soil burning over tropical peatlands has been considered in GFED (Randerson et al., 2012; Giglio et al., 2013; Van Der Werf et al., 2017). Indonesia peat fire emissions are also updated and evaluated in FINN (Kiely et al., 2019). However, compared to above-ground fuel burning, duff emissions are not documented enough by satellitebased global fire emission datasets in forest ecosystems, partially due to the presence of overhead canopies. Another reason is that duff burning usually occurs during the smoldering phase because of the relatively high soil moisture (Ottmar, 2014), and lasts over a long time. Also, the emissions do not rise to high elevations due to low heat release. Thus, the emissions, especially particles, have been thought traditionally to have little impact on regional air quality in populated areas far from the fire site. 
Similar to many world regions (e.g. tropical forests in southeast Asia (Page et al., 2002) and temperate forests in the Great

British Isles (Davies et al., 2013)), the southeastern US is a duff-rich region because of the high humidity and large forest coverage (Zhu and Evans, 1994; Gaffen and Ross, 1999). The warm and moist climate makes vegetation growth and falling leaves and branches decompose fast and therefore accumulate as deep duff, especially in the southern Appalachians (Ottmar and Andreu, 2007) and the Okefenokee swamp (Watts and Kobziar, 2012), which are located in the northern and southern portions of this region, respectively. This region has some unique features among all US regions in the contributions to the carbon cycling and regional air pollution. On one hand, most of the fires in the southeastern US are prescribed and conducted in weather where duff consumption is minimized (Yokelson et al., 2013). Thus, duff burn may be only a small contributor to total pollutant emissions in this region. On the other hand, there are large wildfires that occur under drought conditions and are close to populated areas, although the frequency and severity are usually small relative to those in the western US (Goodrick et al., 2013). Wildfires in the southeastern US usually occur in springs before the summertime rain season starts. Sometimes wildfires can occur in other seasons under drought conditions such as the southern Appalachians fire in fall 2016. As described above, duff burning usually occurs during smouldering phase, however, this situation is changing with more frequent occurrences of droughts, which increases the flammability of the duff layer (Hille and Stephens, 2005). Duff burn during flaming phase of the 2016 Rough Ridge Fire in the southern Appalachian, which occurred during a prolonged severe drought (Park Williams et al., 2017), was reported by fire managers and the related fuel consumption was measured (Zhao et al., 2019).

115 The measured duff layer burned by the fire was $4.6 \mathrm{~cm}$ deep with $31.5 \mathrm{Mg} \mathrm{ha}^{-1}\left(3.15 \mathrm{~kg} \mathrm{~m}^{-2}\right)$ fuel loading, accounting for approximately $60 \%$ of total $\mathrm{PM}_{2.5}$ emitted from the fire. The simulations including duff emissions conducted by Zhao et al. (2019) indicated that the duff burn was a major contributor to the air pollutions in the nearby metro Atlanta. In contrast, a model simulation study on all major 2016 southern Appalachian fires that excluded duff burning resulted in an underestimation of $\mathrm{PM}_{2.5}$ during the fire events (Guan et al., 2020).

The Okefenokee swamp experienced fires during the dry years of 2007, 2011, and 2017, each with much larger burned area than the total burned area from the 2016 southern Appalachian fires. The burning of the duff layer was reported during all three fire events in the Okefenokee region (The 2007 Big Turnaround Fire: https://www.fws.gov/fire/downloads/fire updates/BigTurnaround.FINAL.pdf, $\quad$ the 2011 Honey Prairie Fire: https://www.wunderground.com/blog/weatherhistorian/the-great-okefenokee-swamp-fire-of-2011.html; the 2017 West Mims Fire: https://gatrees.org/wp-content/uploads/2020/02/Wildfire-Damage-Assessment-for-the-West-Mims-Fire.pdf). However, it is not clear how much the duff burning from these fire events contributed to air pollutions in the populated areas.

The literature is still not conclusive on the differing impacts of duff burning on various air pollutants. The emission factors of duff are different from those of above-ground fuels (Yokelson et al., 2013; Urbanski, 2014; Hu et al., 2018; Kiely et al., 2019). For example, the temperate forest duff emission factor of nitrogen oxides $\left(\mathrm{NO}_{\mathrm{x}}\right)$ is $0.67 \mathrm{~g} / \mathrm{kg}$, more than $50 \%$ smaller than the 
conifer forest emission factors. However, the temperate forest duff emission factor of $\mathrm{PM}_{2.5}$ is $50 \pm 16 \mathrm{~g} / \mathrm{kg}$ (Geron and Hays, 2013), which is more than twice of the $\mathrm{PM}_{2.5}$ emission factors from conifer forests (13 - $23 \mathrm{~g} / \mathrm{kg}$ ) (Yokelson et al., 2013; Urbanski, 2014). Because $\mathrm{NO}_{\mathrm{x}}$ is a major precursor of ozone formation, these different emission factors potentially lead to a stronger $\mathrm{PM}_{2.5}$ impact than ozone impact for duff burning.

The goal of this study is to investigate the contributions of duff burning from the largest wildfires this century in the southeastern US to regional air pollutions and the differences between $\mathrm{PM}_{2.5}$ and ozone. The simulations of regional smoke transport were conducted based on the duff measurements from the Rough Ridge Fire (Zhao et al. 2019) and the global fire emission dataset from FINNv1.5. The results are expected to provide important implications for the needs in improving global fire emission inventories and understanding the contributions of duff and peat burnings in other world regions to regional air pollution.

\section{Methods}

\subsection{Study region}

145 The study region is the southeastern US, which comprises the states of Florida, Alabama, Georgia, South Carolina, North Carolina, Tennessee, Mississippi, and Louisiana. This region is dominated by a humid subtropical climate (Belda et al., 2014). The summers are typically long with high temperature and humidity, contributed by the water vapor transport from Bermuda High (Li et al., 2011). The winters are typically dry in peninsular Florida, but relatively wet in the mid-south, such as Tennessee and the northern Georgia and Alabama (Gaffen and Ross, 1999). The ecozones in the southeastern US include broadleaf forest over the Appalachian region in the west of North Carolina and South Carolina, and the north of Georgia, and mixed forest in the other regions including most Georgia and Florida (Bachelet et al., 2001; Blood et al., 2016). Hardwood and pine are major above-ground fuels in the southeastern US (Ottmar and Andreu, 2007). Because of the sufficient light, regularly high humidity and widely distributed deciduous trees that are located in wildlife refuges and regions that lack of prescribed burn removal, the duff layer is accumulated in the southeastern US and contributes as the potential below-ground fuel.

The wildfire cases investigated in this study occurred in two areas. One is the southern Appalachian Mountains in the northern part of the southeastern US. This area is located in the boundaries of Georgia, North Carolina, South Carolina, Tennessee, Virginia, West Virginia, and Kentucky. The Southern Appalachian region is deciduous forests dominated, with small proportions of evergreen forests and mixed forests. The main forest type is the hardwood oak forest (Southern Appalachian Man and the Biosphere, 1996). The other area is the Okefenokee Swamp located across the Georgia-Florida border. The 438,000 acres swamp is mainly covered by the Okefenokee National Wildlife Refuge. Cypress forests and scrub-shrub vegetation are the major vegetation types over the Okefenokee region, and the wetland is covered by a duff layer with a depth 
of up to $4.6 \mathrm{~m}$ (Url: https://www.fws.gov/refuge/okefenokee/, last access: November 17, 2020). The Okefenokee region is sensitive to rainfall. Under drought conditions, the region is vulnerable to wildfire.

\subsection{Fire cases}

In this study, we investigated four wildfire cases (Table 1). The first case included 10 large fires from mid-October to December 2016 in the southern Appalachian mountains during an extreme drought (Konrad and Knox, 2017; Park Williams et al., 2017). The fires burned 91,191 acres of forest, caused losses of 14 lives and massive property loss (McDowell et al., 2017; Pouliot et al., 2017). The largest fires were the Rough Ridge Fire ( $34.88^{\circ} \mathrm{N}, 84.63^{\circ} \mathrm{W}$, ignited on October 16, 27,610 acres burned), the Rock Mountain Fire $\left(34.98^{\circ} \mathrm{N}, 83.52^{\circ} \mathrm{W}\right.$, ignited on November 9, 25,224 acres burned), and the Tellico Fire $\left(35.28^{\circ} \mathrm{N}, 83.58^{\circ}\right.$ W, ignited on November 3, 14,172 acres burned). We denote this case as App16.

The other three cases occurred in Okefenokee in 2007, 2011, and 2017, respectively. We denote them as Oke07, Oke11, and Oke17. The 2007 Okefenokee mega wildfire was ignited in the Okefenokee Wildlife Refuge $\left(30.67^{\circ} \mathrm{N}, 82.45^{\circ} \mathrm{W}\right)$ on April

175 16, and burned more than 500,000 acres until late June (Fire Behavior Assessment Team, 2007). Protracted drought led to low water levels in the Okefenokee swamp provided the condition of burning in a mix of shrub scrub, wetland prairies, duff, cypress and long-leaf pine forests. This fire remains the largest wildfire in the history of Georgia and Florida (Url: https://www.fws.gov/fire/downloads/fire_updates/BigTurnaround.FINAL.pdf, last access: October 29, 2020).

180 The 2011 Honey Prairie Fire was ignited on April 30 under a severe drought, during which the Okefenokee Swamp water level was lower than that during the 2007 mega-fire (https://www.fws.gov/refuges/news/HoneyPrairieFire_05112011.html, last access: December 3, 2020). 147,065 acres were burned (Finco et al., 2012). The 2017 West Mims Fire was ignited on April 6 under an extreme drought and developed fast in early May (http://www.gatrees.net/forest-management/forest-health/alertsand-updates/Wildfire\%20Damage\%20Assessment\%20for\%20the\%20West\%20Mims\%20Fire.pdf, last access: December 3, 2020). 166,737 acres were burned.

\subsection{Model simulations}

\subsubsection{Model}

The model components and implementation procedure used for simulations are illustrated in Fig. 1. We used WRF-Chem version 3.9.1 (Grell et al., 2005; Fast et al., 2006; Powers et al., 2017) to simulate the aerosol, gas transport, and atmospheric chemistry over the southeastern US. The model has coupled gas-phase atmospheric chemistry (Wang et al., 2015; Zhang et al., 2016), aerosol optical properties (Barnard et al., 2010), and the new Thompson graupel microphysics scheme (Thompson et al., 2008). The radiation scheme is the Rapid Radiative Transfer Method for Global Climate Models (GCMs) (RRTMG) (Iacono et al., 2008; Mlawer et al., 1997). The kinetic preprocessor (KPP) library was used for chemical reactions (Damian et 
al., 2002; Sandu et al., 2003; Sandu and Sander, 2006). The $1^{\circ} \times 1^{\circ}$ meteorological data from National Centers for used as the meteorological initial and boundary conditions for the simulations.

The Model for Ozone and Related chemical Tracers (MOZART) (Emmons et al., 2010) was used as the WRF chemistry module, coupled with Georgia Tech/Goddard Global Ozone Chemistry Aerosol Radiation and Transport (GOCART) aerosol scheme (Chin et al., 2002). Madronich F-TUV photolysis scheme was applied, with a time step of 15 minutes (Madronich, 1987). The time step was 3 minutes for chemistry. Gas and aerosol dry deposition, aerosol wet scavenging, vertical mixing, subgrid convective transport, and subgrid aqueous chemistry (Peckham et al., 2018) were included in the model simulations. The global simulation result from MOZART (Pfister et al., 2011b) was used as the chemical initial and boundary conditions of the simulation in this study. The ozone initial and boundary conditions from MOZART were also scaled by comparing the mean surface ozone concentration over the simulation domain with the US EPA Air Quality System (AQS) observations (https://www.epa.gov/outdoor-air-quality-data, last access: October 22, 2020).

\subsubsection{Simulation domains}

The simulation domain for App 16 was from $30.4^{\circ} \mathrm{N}$ to $37.5^{\circ} \mathrm{N}$ and from $88.3^{\circ} \mathrm{W}$ to $77.7^{\circ} \mathrm{W}$, with a spatial resolution of 12 $\mathrm{km}$. This domain included the major burning sites and the downwind nearby large cities including Atlanta $\left(33.75^{\circ} \mathrm{N}, 84.39^{\circ}\right.$ $\mathrm{W})$ and Charlotte $\left(35.23^{\circ} \mathrm{N}, 80.84^{\circ} \mathrm{W}\right)$. The simulation period was November 7 - 22, 2016. The daily trend of FINN organic carbon (OC) emissions over the fire region is shown in Fig. S1, indicating that the simulation period cases contained the most severe burning that occurred during the fire case.

215 The simulation domain for the three Okefenokee cases was from $23.9^{\circ} \mathrm{N}$ to $37.0^{\circ} \mathrm{N}$ and from $92.6^{\circ} \mathrm{W}$ to $72.4^{\circ} \mathrm{W}$, with a spatial resolution of $12 \mathrm{~km}$ (Fig. S1). The Okefenokee Wildlife Refuge was located at the center of this domain. Nearby cities and the ocean were included to evaluate the smoke transport to urban and remote areas. The simulation periods were May 630, 2007, May 4-15, 2011, and April 19 - May 13, 2017, respectively.

\subsubsection{Simulations and evaluations}

220 For each fire case, we conducted three simulations to evaluate the air quality impacts from fires and duff burning (Table 1). (1) sim_nofire: no fire emissions; (2) sim_FINN: FINNv1.5 fire emission dataset was used as the fire emission input, but duff burning was not included in this dataset; (3) sim_FINN+duff: same as sim_FINN but with duff burning emissions. We used the differences in the results between sim_FINN and sim_nofire to represent the impacts from fire, and the differences between sim_FINN+duff and sim_FINN to represent the impacts from duff burning. 
We evaluated the model performances in simulating air pollutant concentrations by comparing them with the EPA Air Quality System (AQS) in-situ hourly observations for $\mathrm{PM}_{2.5}$ and ozone (https://www.epa.gov/outdoor-air-quality-data, last access: October 22, 2020). Starting in 2008, EPA included the Federal Reference Methods (FRM) or Federal Equivalent Methods (FEM) for the particulate measurement as a systematic framework, which provides standard methodologies and procedures for measuring and analyzing PM (Noble et al., 2001). During Oke07, the FRM/FEM was not spread out in the $\mathrm{PM}_{2.5}$ measurement system from EPA AQS. For the consistency of all the fire cases, both FRM/FEM and non-FRM/FRM datasets were used for comparison.

The day-time surface ozone concentrations, calculated by averaging surface ozone concentrations from local time 10 am to 6 pm, were evaluated between the baseline simulations (sim_FINN) and the observations. In the model evaluation and the following result analysis, the surface concentrations in the simulation are defined as the concentrations at the bottom layer in the model, which was also the layer where the surface emission input was added in.

\subsection{Emission data}

\subsubsection{Fire emissions of above-ground fuels}

240 The fire emissions from FINNv1.5 were implemented into WRF-Chem by Pfister et al. (2011a), which contains the daily burned area and emissions of an amount of gas and aerosol species with a spatial resolution of $1 \mathrm{~km}$ (Wiedinmyer et al., 2011). The plume rise calculation of the fire emission using a 1-D time-dependent dynamic cloud model was called every 30 minutes (Freitas et al., 2007; Grell et al., 2011). The high-resolution in both space and time with the FINN fire data is a valuable feature for this study.

The biogenic emissions from the Model of Emissions of Gases and Aerosols from Nature (MEGAN) (Guenther, 2006; Sakulyanontvittaya et al., 2008) were used as the WRF-Chem input, from which monthly biogenic emissions with a spatial resolution of approximately $1 \mathrm{~km}$ were derived. The dust, dimethylsulfide (DMS) and sea salt emissions from GOCART were included in the model (Ginoux et al., 2001; Chin et al., 2002). For the model anthropogenic emission input, we used the NEI 2014v2 hourly anthropogenic emission dataset for the U.S., based on the criteria pollutant emissions from the 2014 EPA platform (USEPA, 2018b) implemented for the National Air Toxics Assessment (USEPA, 2018a). During the simulation, the meteorological field was nudged towards the $1^{\circ} \times 1^{\circ}$ NCEP FNL reanalyses (FNL NCEP, 2000) every 6 hours, using the WRF Four-Dimensional Data Assimilation (FDDA) method (Stauffer and Seaman, 1990).

\subsubsection{Fire emissions of duff}

255 Current major global fire emission inventories, such as GFED and FINN (Wiedinmyer et al., 2011; Giglio et al., 2013; Van Der Werf et al., 2017), do not include enough duff and peat emissions. The fuel loading in FINN is based on the regional 
average from Global Wildland Fire Emission Model (GWEM) (Hoelzemann et al., 2004). Total fuel loading of each grid is assigned with one of specific land cover classifications. Litter is included in GWEM, but peat and duff are not. In contrast, duff is explicitly included in GFED. GFED4s assumes the $\mathrm{PM}_{2.5}$ emission factor of $9.1 \mathrm{~g} / \mathrm{kg}$ from duff and peat burning based on Andreae and Merlet (2001), which is smaller than the above-ground fuel emission factors, and significantly smaller than the recent field and experiment results (Yokelson et al., 2013; Urbanski, 2014). Andreae (2019) updated the $\mathrm{PM}_{2.5}$ emission factor of peat burning to $18.9 \mathrm{~g} / \mathrm{kg}$, which is larger than the above-ground fuel emission factors, but the latest fire emission inventory has not been updated accordingly yet.

The amount of duff burned during the fire cases investigated in this study was estimated based on the measurements from Zhao et al. (2019). During the 2016 Rough Ridge Fire, $4.6 \mathrm{~cm}$ of a duff layer was burned within one day, which accounted for more than $90 \%$ of the total duff. The duff burning contributed $60 \%$ of the total $\mathrm{PM}_{2.5}$ emission. To our best knowledge, this measurement is the only duff burned depth measurement during the flaming phase in the temperate region. In previous studies, duff burning in the smoldering phase was evaluated. For example, the duff smoldering depth in North Carolina peat fires were measured from $0.5 \mathrm{~cm}$ to $10 \mathrm{~cm}$ (Wilbur and Christensen, 1983; Poulter et al., 2006), and Watts (2013) estimated $8.9 \pm 5.2 \mathrm{~cm}$ duff burn depth during the smoldering in cypress swamps in Florida. Light detection and ranging (LiDAR) instruments detected an approximately $47 \mathrm{~cm}$ soil elevation loss during the 2011 Lateral West fire in a swamp in Virginia (Reddy et al., 2015). Because smoldering occurs at a low temperature in the long-term (months to years) (Rein and Belcher, 2013), which just creates weak and low plumes, here we only studied the regional air quality impact from duff flaming.

The duff emission estimation in this study is described in Fig. 2. We estimated duff emissions and added them to FINN with the following method. First, we calculated the daily duff mass burned, $M(x, y, t)\left(\mathrm{kg} \mathrm{day}^{-1}\right)$, in the burning case over the model grid box $(x, y)$ on the day $(t)$ :

$M(x, y, t)=a(x, y, t) h \rho$,

280 where $a(x, y, t)$ is burned area $\left(\mathrm{m}^{2}\right), h$ is the average duff-layer depth burned daily in the case $\left(h=0.045 \mathrm{~m}_{\text {day }}{ }^{-1}\right.$ assumed $)$, and $\rho$ is the density of duff, which was assumed to be $57.4 \mathrm{~kg} \mathrm{~m}^{-2} \mathrm{~m}^{-1}$ according to the measurements over the southeastern US with the vegetation type of Pine and Hardwoods (Ottmar and Andreu, 2007). The measurements from different locations showed a $21 \%$ standard error of mean duff density.

285 The duff emissions were then added to FINN fire emission $E(x, y, t)_{F I N N+d u f f, s}\left(\mathrm{~kg}\right.$ day $\left.{ }^{-1}\right)$ for each grid box, day, and species $(s)$ :

$E(x, y, t)_{F I N N+d u f f, s}=E(x, y, t)_{F I N N, s}+M(x, y, t) * E F_{s} * 0.001$

where $E(x, y, t)_{F I N N, S}$ is the original FINN fire emission, and $E F_{S}$ is the duff emission factor of the species s $(\mathrm{g} / \mathrm{kg})$. 
The $\mathrm{PM}_{2.5}$ emission factor of duff / peat burning varies noticeably among the studies across the world regions and ecosystems (Table S1). The four studies in the southeastern US obtained average values of about $50 \mathrm{~g} / \mathrm{kg}$ (for ground fire, Geron and Hays, 2013), $5.5 \mathrm{~g} / \mathrm{kg}$ (Black et al. 2016), $44 \mathrm{~g} / \mathrm{kg}$ (Benner 1977), and $30 \mathrm{~g} / \mathrm{kg}$ (McMahon et al. 1980). The first two studies took soil samples from the same peat location in eastern North Carolina, US. Due to a previous fire investigated by the first study, the sample from the second one had much less carbon but more ash. This was a major reason for the much lower $\mathrm{PM}_{2.5}$ emission factor proposed by the authors. For this reason, we did not consider the value from the second study when we specified the emission factor value for our study. The value from the first study was used as the US temperate duff burning emission factor in the review paper by Urbanski (2014). It was also used in our study because it is likely to better represent the burning on the vegetation type in the southeastern US.

As described in the introduction section, the differences in emission factors between duff and above-ground fuels suggest different impacts of duff burning on $\mathrm{PM}_{2.5}$ and ozone. The emission factor of $\mathrm{PM}_{2.5}$ from duff burning used in this study (50 $\mathrm{g}$ $\left.\mathrm{kg}^{-1}\right)$ is more than 3 times that from forest burning $\left(13 \mathrm{~g} \mathrm{~kg}^{-1}\right)$. However, the emission factors of $\mathrm{NO}_{\mathrm{x}}$ from duff burning $(0.559$ $\mathrm{g} \mathrm{kg}^{-1}$ for $\mathrm{NO}$ and $0.176 \mathrm{~g} \mathrm{~kg}^{-1}$ for $\left.\mathrm{NO}_{2}\right)$ are less than $25 \%$ of those from forest fire $\left(0.34 \mathrm{~g} \mathrm{~kg}^{-1}\right.$ for NO and $2.7 \mathrm{~g} \mathrm{~kg}^{-1}$ for NO $\left.\mathrm{NO}_{2}\right)$.

For App16, where fires had been absent for decades before 2016 in many fire sites, emissions from duff burning were calculated using the measured depth of duff burn at the Rough Ridge Fire site. The situation was the same for Oke07. However, some areas of Oke11 were overlapped with those of Oke07, while some burned areas of Oke17 overlapped with those of Oke07 and/or Oke11. From the FINN emission dataset, 87\% of the burned area in Oke11 was burned by Oke07, and 79\% of Oke17 was burned by the 2007 and 2011 fires. We assumed a duff layer recovery rate of $1 \mathrm{~mm} / \mathrm{year}$ based on previous studies (Ovenden, 1990; Frolking et al., 2001; Borren et al., 2004; Milner et al., 2020). Only a fraction of the measured burned duff depth for the Rough Ridge Fire (Zhao et al., 2019) was assumed for the reburned areas. For example, if the burning during Oke11 was also burned in 2007, only $4 \mathrm{~mm}$ of the duff layer was assumed to be burned and the related duff emissions were added to the 2011 sim_FINN+duff run.

\subsection{Sensitivity experiments}

Many fire inventories using satellite based models often underestimate fire emissions for a variety of reasons (clouds, small burned areas, timing, etc.) (Wiedinmyer et al., 2011) and a-priori emissions are normally scaled up to improve model measurement agreement (Ward et al., 2012). We found that the burned area in all four wildfire cases from FINN was approximately 50\% less than the burned area summarized in Monitoring Trends and Burn Severity (MTBS) (Eidenshink et al., 
also lower approximately at this rate than the calculated emissions from based on the measured above-ground fuel consumption by the Rough Ridge Fire in northern Georgia on November 10 and 14, 2016 (Zhao et al. 2019). We did not use the commonly used approach to scale up the FINN emissions because we wanted to understand if the missing duff burning contributed to the underestimate FINN emissions to a certain extent. This FINN emission underestimate would lead to uncertainty in quantitatively estimating the contribution relative to the above-ground fuel consumption. We did a sensitivity experiment by doubling FINN emissions for the Oke07 case (exp_FINN, Table 1) to roughly assess the uncertainty.

As described above, there are large variations in $\mathrm{PM}_{2.5}$ emission factor. Also, there were not enough duff measurements for the fire cases we investigated. To evaluate the uncertainty of our simulation results due to high spatial variation of the duff layer depth, we conducted week-long sensitivity runs for App16 and Oke07 with changes of the duff burning rates by $\pm 20 \%$ (exp_duff, Table 1).

\section{Results}

\subsection{Comparisons between simulations and observations}

For both sim_nofire and sim_FINN, the simulated $\mathrm{PM}_{2.5}$ concentrations agree with the observations over the areas not influenced by fire events (Fig. S3). However, the baseline simulation (sim_FINN) underestimates $\mathrm{PM}_{2.5}$ concentrations over the fire-impacted areas, shown in Fig. 3. For example, in the App16 areas $\left(34.5^{\circ} \mathrm{N}\right.$ to $36^{\circ} \mathrm{N}, 82^{\circ} \mathrm{W}$ to $\left.84^{\circ} \mathrm{W}\right)$, the model underestimates $\mathrm{PM}_{2.5}$ by $56.6 \%$ for sim_nofire and by $29.2 \%$ for sim_FINN. For Oke07 and Oke11, the massive plume simulated by the model is transported to a large area of Georgia. The model underestimates $\mathrm{PM}_{2.5}$ in Georgia by $56.2 \%$ in 2007 and $49.0 \%$ in 2011 for sim_nofire, and $47.5 \%$ in 2007 and 39.5\% in 2011 for sim_FINN. The simulated smoke from

340 Oke17 disperses more widely in space than that from Oke11, so the intensity of the mean fire impact is minor. The comparisons of time series comparison show similar results, that is, sim_FINN underestimated $\mathrm{PM}_{2.5}$ surface concentrations (Fig. 3). Figure 3 also shows a $\mathrm{PM}_{2.5}$ increase in all the 4 cases due to duff emissions, which improves the overall model performance, although the simulations still underestimate in the Oke11 and Oke17 cases, and slightly overestimates the $\mathrm{PM}_{2.5}$ level in the App16 case.

345 The model is able to reproduce the spatial distributions of surface ozone for all fire cases (Fig. S7). The baseline (sim_nofire) runs capture the observed background daytime ozone concentrations and the concentrated $\mathrm{PM}_{2.5}$ spots (the spots with highlevel surface $\mathrm{PM}_{2.5}$ concentrations directly due to fire smoke) in the fire and remote areas. For example, the model reproduces the high ozone concentrations from northern Alabama and Georgia to northwestern South Carolina and North Carolina and eastern Tennessee, as well as the coastal Louisiana and Mississippi and central Florida from Oke07 (Fig. S7f). However, the model overestimates surface ozone in the western South Carolina and North Carolina mountains (Fig. S7c and Fig. S7g). This might be caused by the uncertainty of estimating biogenic VOC emissions. 
The observed ozone maximum 8-hour average (MDA8) shows an agreement with the baseline simulation for all fire cases. The observation-simulation correlation coefficients are larger than 0.5 for App16 and larger than 0.6 for the Okefenokee cases (Fig. S4). Both sim_FINN and sim_FINN+duff simulations also agree with the observations in terms of the time series and trend during the fire events (Fig. 4). The model overestimates night-time ozone by approximately $10 \mathrm{ppb}$ for App16, indicating the potential bias on night-time ozone chemistry or planetary boundary layer height estimation (Li and Rappenglueck, 2018).

While the sim_FINN simulations underestimate $\mathrm{PM}_{2.5}$ concentrations over the burning region, especially sites with the smoke impact, sim_FINN+duff simulations have better agreement with the observations, as shown in Fig. S5. The slope of the linear regression is 0.91 between sim_FINN+duff results and the observations, while the slope is only 0.15 between sim_FINN and observations. Although adding duff burning improves the regional simulation in terms of both the slope and the correlation coefficient (from 0.29 to 0.56 ), the correlation coefficient is still low, indicating the potential spatial-temporal uncertainty of the fire emissions. The evaluations for the SA16, Oke11 and Oke17 fires are similar to the Oke07 results as shown in Fig. S5.

The model performance in simulating the spatial patterns of smoke is evaluated by the Moderate Resolution Imaging Spectroradiometer (MODIS) image product from the Terra satellite. Fig. S6 shows that the simulated smoke transport agrees well with the satellite image of the smoke. The results in the Oke07, Oke11 and Oke17 fires also shows good agreement between the simulation and the satellite image. In the following sections, we will further discuss the spatial and temporal patterns of smoke ozone and $\mathrm{PM}_{2.5}$.

\subsection{The PM2.5 emission and transport from duff burning}

Here we show the improvement of model performance in simulating $\mathrm{PM}_{2.5}$ by including duff burning emissions. The simulation results on selected dates of November 15, 2016, May 10, 2007, May 8, 2011, and April 29, 2017 for the four fire cases are shown in Fig. 5 and Fig. 6, and those on other days are provided in Figs. S8 to S15.

The sim_FINN simulated smoke from App16 is transported southeastward to Georgia, South and North Carolinas on November 15, 2016 (Fig. 6a and Fig. 6e), leading to increased air pollution. However, the model underestimates the observed surface $\mathrm{PM}_{2.5}$ concentrations by approximately $50 \%$ in areas with peak local concentration (Fig. 5e). On November 10 and 16 , 2016, the simulated plume moves in the clockwise direction, causing air pollutions in the large cities in Georgia (Fig. S9). Fig. 6a and Fig. 6e indicate that the $\mathrm{PM}_{2.5}$ concentrations from duff burning are at the same magnitude as or even slightly higher than those from the emissions of above-ground fuel burning. Thus, implementing duff burning doubles the $\mathrm{PM}_{2.5}$ concentrations from App16. 
The total burned area of Oke07 was 5 times more than that of App16. The emissions were larger from Oke07 and correspondingly the simulated $\mathrm{PM}_{2.5}$ concentrations are greater. In addition, different from App16 that occurred in November, Oke07 occurred in May. Thus, the photochemistry of ozone and its precursors was more active. In the sim_FINN+duff runs, the simulated fire plume effectively approaches the underestimated regions, but the enhancement is still not enough over some regions. For example, on May 10, the simulations including duff emissions are in better agreement with the observation over southwestern Florida, where the simulated concentrations are underestimated by a factor of 2-5 (Fig. $5 \mathrm{f}$ and Fig. 5j). Over the fire impacted region $\left(24^{\circ} \mathrm{N}-34^{\circ} \mathrm{N}, 76^{\circ} \mathrm{W}-86^{\circ} \mathrm{W}\right)$ on May 10 , the surface $\mathrm{PM}_{2.5}$ increase due to duff burning is $126 \%$ more than that due to above-ground fuel burning. However, the simulation that is the closest to the observation still underestimates the surface $\mathrm{PM}_{2.5}$ concentrations in the fire impacted region in northern Georgia and North Carolina. The sim_FINN simulation underestimates some concentrated $\mathrm{PM}_{2.5}$ during the fire, including southwest Florida on May 11, the Atlanta region on May 16, and western Georgia on May 26, by as much as more than 10 times sometimes (Fig. S9).

Similar to the other cases, the sim_FINN+duff simulated surface $\mathrm{PM}_{2.5}$ concentrations from Oke11 and Oke17 are approximately doubled over the fire areas of those simulated in sim_FINN (Fig. 6c, 6d, 6g and 6h). However, the sim_FINN simulation of the fire cases does not underestimate $\mathrm{PM}_{2.5}$ as much as Oke07. Because a large portion of the two fires was burned by the previous fires in 2007 (and 2011 for the 2017 fire), the simulated duff impacts from them are weaker. In addition,

400 the simulated smoke from the two fires is transported to the ocean during half of the major burning periods (May 9 - 11, 2011 and May 2 - 12, 2017) (Fig. S14 and Fig. S15), which weakens the fire impact in the land areas. This inter-case comparison over the same area supports the evidence that the underestimation of $\mathrm{PM}_{2.5}$ in the sim_FINN runs is mainly due to the missing of duff burning emissions.

405 The important $\mathrm{PM}_{2.5}$ impacts of duff burning are also seen in the temporal variations of stational surface concentrations (Fig. 7). The panels $7 \mathrm{a}, \mathrm{d}, \mathrm{g}$ and $\mathrm{h}$ show the locations close to the fire areas. During App16, the simulated $\mathrm{PM}_{2.5}$ concentrations increase by approximately $100 \%$ during the major burning days on November $7,8,13,14$ and 15, due to including duff burning (Fig. 7a). The daily variations are different between observations and simulations because the observed fire emission dataset was at daily rather than hourly intervals. The sim_FINN+duff improves the simulations of $\mathrm{PM}_{2.5}$ surface concentrations in metro Atlanta, Georgia (Fig. 7b) and metro Charlotte, North Carolina (Fig. 7c) on major burning days.

During Oke07, including duff burning makes the simulated $\mathrm{PM}_{2.5}$ levels 1 to 10 times closer to the observed $\mathrm{PM}_{2.5}$ levels at many observation locations, for example, on May 9 and May 18 in Duval County, Florida (Fig. 7d), and May 8 to May 13 in Orange County, Florida (where metro Orlando is located) (Fig. 7f). The simulation shows a high bias on May 27 in Duval, 415 potentially due to the bias on fire emissions, but on the same day, the simulation still underestimates the $\mathrm{PM}_{2.5}$ concentrations in Atlanta, Georgia. Duff emission increases the $\mathrm{PM}_{2.5}$ concentrations in Atlanta (Fig. 7e), but the model underestimation still exists. 
Because of the weak impacts of duff burning during Oke11 and Oke17 on $\mathrm{PM}_{2.5}$ in metro areas as shown above, we evaluated sim_FINN+duff model performance by comparing with in-situ observation at the locations close to the fire site (Fig. $7 \mathrm{~g}$, $\mathrm{h}$ ). Although the sim_FINN+duff simulation overestimates PM $_{2.5}$ concentrations on May 7, 2011, May 2 - 3, 2017 and May 7, 2017, adding duff burning generally reduces the $\mathrm{PM}_{2.5}$ underestimation in sim_FINN runs on May 9, 12, 14, 2011 , April 24 26 and May 9 - 13, 2017. Duff burning increases local $\mathrm{PM}_{2.5}$ concentration by 50-400\%, depending on the above-ground fuel burning and the duff recovery conditions.

There are large mismatches at times between observations and simulations. Both biases in fire emission calculation and smoke transport simulation should be the contributors. In addition to the uncertainties with the FINN fire emissions and duff emission calculation described above, fires have large diurnal variations, but only daily burned area data for emission calculation were available. Despite the general agreement in spatial patterns between the simulated and satellite detected smoke plume as shown above, biases in WRF simulations of atmospheric conditions, especially wind direction and speed, would lead to shifts in both space and time of the simulated plume from its actual position.

\subsection{The different ozone and PM2.5 impacts from duff burning}

Although the above-ground fuel burning of App16 led to a 6 - 10 ppb increase of surface ozone on November 15 , 2016 (Fig. 8a) over the areas affected by fire plume, adding duff burning to the model simulation does not increase the surface ozone concentration. Over the downwind region where the ozone increase is high from above-ground fuel burning, duff burning slightly offset the ozone increase by $0-4 \mathrm{ppb}$. A similar minor ozone impact from duff burning is also simulated for other days (Fig. S20). The ambient VOC concentrations are lower in November than that in summer, which provides a VOC-limited scenario in the ozone photochemistry. In this scenario, when NOx concentration is high due to the above-ground fuel burning, more NOx emissions from duff burning tend to decrease ozone concentrations (Seinfeld and Pandis, 2016). The above-ground fuel burning increases ozone concentrations by 10 - $15 \mathrm{ppb}$ on November 13 - 15, but the ozone concentrations in sim_FINN+duff are very similar to those in sim_FINN, indicating that the duff burning has a neglectable impact on ozone concentrations in App16 (Fig. 10a-c). The ozone simulation agrees better with observations in the urban than in the rural fire areas, and similarly to the fire area, the ozone in the urban areas is not significantly affected by duff burning.

445 The simulated duff burning impact on ozone is positive during Oke07, but still smaller than the PM 2.5 impact. The aboveground fuel burning and the duff burning increase the ozone concentration in the fire-impacted areas (Fig. 9b and 9f, Fig. S21). Oke07 occurred in summer and the fire site was located further south in comparison with App16, meaning higher temperature, sunlight and biogenic activities. Thus the overall VOC concentrations and the simulated ozone pollution are stronger than those in November 2016 (Seinfeld and Pandis, 2016). However, the ozone impact is significantly weaker from duff burning than from above-ground fuel burning (Fig. 9b and 9f, Fig. S21). The simulated surface ozone increase due to duff burning is 
only $32 \%$ of that due to above-ground fuel burning over the fire impacted region $\left(24^{\circ} \mathrm{N}-34^{\circ} \mathrm{N}, 76^{\circ} \mathrm{W}-86^{\circ} \mathrm{W}\right)$ on May 10 , 2007. This contribution is much smaller than that of duff burning to the $\mathrm{PM}_{2.5}$ impact, which is $126 \%$ more than that from above-ground fuel burning. These different contributions of duff burning to $\mathrm{PM}_{2.5}$ and ozone are due to the larger $\mathrm{PM}_{2.5}$ emission factor but smaller $\mathrm{NO}_{\mathrm{x}}$ emission factors of duff in comparison with the above-ground fuel, as assumed in Section 2.4.

The difference is also seen in the temporal variations. The above-ground burning led to ozone increases by $10-20 \mathrm{ppb}$ in Atlanta on May 21 - 23 (Fig. 10e) and by 2 - 15 ppb in Orlando on May 8 - 12 (Fig. 10f), but duff burning led to ozone increases by $0-7$ ppb in both Duval (Fig. 10d) and Orlando (Fig. 10f) on May 8 - 12.

The ozone increase is significant due to the above-ground fuel burning from Oke11 and Oke17 (Fig. 9c and Fig. 9d), with a level comparable to Oke07. However, the level of ozone increase due to duff burning is low (Fig. 9g and Fig. 9h). This low level is also seen in the temporal variations (Fig. 10g, Fig. 10h). The sim_FINN and sim_FINN+duff runs accurately capture several ozone peaks on May 8 and May 10, 2011, May 2 and May 8 - 13,2017. Duff's contribution to the ozone peak is weak, similar to that of $\mathrm{PM}_{2.5}$. The duff layer in the Okefenokee swamp in 2011 and 2017 was not well recovered from Oke07.

465 The ozone and $\mathrm{PM}_{2.5}$ impacts from duff burning and the above-ground burning in the fire areas $\left(6^{\circ} \times 6^{\circ}\right.$ in size centered at the fire site) and nearby areas are summarized in Table 3 . The above-ground fuel burning significantly increases ozone over the fire area in all cases except 2017, but duff burning does not affect ozone concentrations significantly. However, duff burning has comparable $\mathrm{PM}_{2.5}$ impacts to above-ground fuel burning in all the fire cases. Duff burning also significantly affects urban air quality during App16 and Oke07. During 2007, when duff burning in the simulation is strong in the Okefenokee swamp, the duff impact accounts for double that of the above-ground fuel impact. During Oke11 and Oke17, the duff impacts are weaker due to the slow recovering speed of the duff layer after the 2007 fire, but the $\mathrm{PM}_{2.5}$ impact is still significant over the fire area.

\section{3.4 Sensitivity runs}

The result from exp_FINN shows that doubling FINN emission does not affect our simulation results, as shown in Fig. S26. In comparison with the regional $\mathrm{PM}_{2.5}$ underestimation of $36 \%$ with no duff burning, doubling FINN emission reduces the underestimation to $20 \%$. However, doubling FINN emission does not fix the problem of missing some fire peaks on dates like

May 8, 11 and 14. Simulations of all four fire cases shown in Fig. S26 overestimate the $\mathrm{PM}_{2.5}$ on May 12, potentially due to the model bias on fire emission timing and the smoke transport. 
The result from exp_duff (Fig. S24-25) shows that the uncertainty of duff emission does not affect our finding of the different $\mathrm{PM}_{2.5}$ and ozone effects by duff burning. The $\mathrm{PM}_{2.5}$ concentrations change by $\pm(9.5-13.2) \%$ near the fire site for App 16 , and \pm (2.6 - 14.9) \% for Oke07 (Fig. S24a and Fig. S24c). The ozone concentrations change within $\pm 2 \%$ (Fig. S25). The PM 2.5 concentrations change by \pm (5.5 - 10.1) \% in Charlotte, North Carolina for App16, and \pm (2.3 - 11.5) \% in Orlando, Florida for Oke07 (Fig. S24b and Fig. S24d).

\section{Conclusions and discussion}

Duff burning emissions have been calculated from the largest wildfires in this century in the moist southeastern US based on our previous field measurements at the site of the Rough Ridge Fire, one of the fires investigated in the study, and atmospheric $\mathrm{PM}_{2.5}$ and ozone concentrations have been simulated using WRF-Chem with the duff burning emissions added to the FINN fire emission inventory. The results indicate that contributions from duff burning to the air pollutions are comparable, and sometimes more than the burning of above-ground fuels, which supports the previous finding from a study of the Rough Ridge Fire (Zhao et al. 2019). The WRF-Chem simulations of all the fire cases including duff burning show better agreements with the observed $\mathrm{PM}_{2.5}$ surface concentration than the baseline simulations which include only fire emissions from above-ground fuel burning. Thus, regional air quality modeling in the southeastern US can be substantially improved by adding duff burning emissions in the existing fire emission datasets. It is further concluded that the impacts of duff burning on $\mathrm{PM}_{2.5}$ are much more remarkable than those on ozone. The simulation results indicate that the above-ground fuel burning increases regional ozone surface concentrations, but the ozone changes due to duff burning are statistically insignificant.

The importance of duff burning contribution to $\mathrm{PM}_{2.5}$ concentrations suggests an effective approach to improve regional air quality simulations in the other global regions with deep and peat duff accumulations. As described before, current major fire emission inventories, such as GFED and FINN (Wiedinmyer et al., 2011; Giglio et al., 2013; Van Der Werf et al., 2017), do not include enough duff and peat emissions. FINN v1.5 applied the emission factors mainly based on Andreae and Merlet (2001) and Akagi et al. (2011) but the emission factors of duff and peat burning are not included. On the other hand, Tansey et al. (2008) investigated the uncertainties of burned area and satellite fire hotspots over the tropical peatlands, indicating that duff burning in the emission inventories based on satellite data is highly uncertain. This potentially leads to significant underestimation over fire events with duff and peat burning, which further affects the evaluation of the regional air quality and human health impacts (Reid et al., 2016). 
One major uncertainty in this study is the amount of duff burned in the Okefenokee fires. Although reports show that during the 2007 Okefenokee extreme drought and fire, 2 feet $(61 \mathrm{~cm})$ of duff thicknesses reduction was observed in some intensively burned areas, which potentially due to the combination of burning and deflation of domed duff and peat surfaces, an average duff consumption for simulation is not provided from measurements (Johnson and Schmerfeld, 2016). In the sensitivity runs described in Section 3.4, we indicate that this bias has a minimal effect on the major findings of the large $\mathrm{PM}_{2.5}$ impact from duff burning and the different impacts between $\mathrm{PM}_{2.5}$ and ozone. Another uncertainty is the values used in the duff emission calculation, for example, the bulk density of duff mass and the emission factors of different species from duff burning. We used $50 \pm 16 \mathrm{~g} / \mathrm{kg} \mathrm{PM} 2.5$ emission factor for duff burns in this study based on fires in North Carolina (Geron and Hays, 2013; Urbanski, 2014), which is closest to the fire sites. It is comparable to some other peat fire measurements in the southeastern US such as $44 \pm 9 \mathrm{~g} / \mathrm{kg}$ from Benner (1977) and $30 \pm 20 \mathrm{~g} / \mathrm{kg}$ from McMahon et al. (1980). However, the spatial variability of duff bulk density is large in the southern US, ranging from 39.4 to $103.7 \mathrm{~kg} \mathrm{~m}^{-2} \mathrm{~m}^{-1}$ (Ottmar and Andreu, 2007).

Many evaluation studies have indicated that WRF-Chem is able to provide ground ozone simulations within reasonable biases, less than 20\% for Europe (Mar et al., 2016) and 15-30\% for the western, northeastern and midwestern US (Astitha et al., 2017). However, ozone simulation within plume is much more complexed, depending on many factors such as emissions of ozone precursors, photochemical processes, radiation change and temperature changes due to smoke, and lifetime of smoke, which make simulate ozone from wildfires challenging (Jaffe and Wigder, 2012). Our simulations did not consider the impacts of smoke on radiation, possibly leading to overestimating ozone production in plume (Selimovic et al., 2020). We conducted a test simulation for the Ofe 07 case by including the impacts to evaluate the related uncertainty in ozone simulations. The result shows that missing the aerosol radiation impacts leads to approximately $15 \%$ of ozone overestimation in the fresh plume, and $10 \%$ of ozone increase in the aged plume. Further evaluation of ozone simulation in fire plume is needed. The recent implements of many field campaigns, especially Western wildfire Experiment for Cloud chemistry, Aerosol absorption and Nitrogen (WE-CAN) (https://www2.acom.ucar.edu/campaigns/we-can), are expected to help fill the evaluation and simulation gaps.

The findings from this study on the air quality impacts of wildfires in the southeastern US are valuable for future studies and can serve as guidance for other global regions with duff and peat burning such as northeastern China (Jiang et al., 2008) and the Great British Isles (Davies et al., 2013). In the southeastern US, the general high humidity provides good conditions for the duff layer to accumulate, which serves as a large potential fuel source during wildfires under droughts. The peatland in boreal forests (e.g. the boreal forest in Canada and Northern Eurasia) and tropical forests (e.g. the peatland in Indonesia) are also vulnerable to fire. Although the duff and peat layer and the burning types vary with ecosystems, the carbon loss from duff 545 and peat fire and the different emission factors between the below-ground fuel and above-ground fuel are common issues (Page et al., 2002; Turetsky et al., 2015), which need to be addressed as what was conducted for the southeastern US in this study. The $\mathrm{PM}_{2.5}$ emission factor used in this study is higher than the measurements in the other regions, such as $20.6 \mathrm{~g} / \mathrm{kg}$ estimated 
in the US prescribed burning (Yokelson et al., 2013), 8-58 g/kg measured in fires in Southeast Asia (Roulston et al., 2018), and $18.9 \mathrm{~g} / \mathrm{kg}$ from global estimation summarized by Andreae (2019). This difference suggests that the impacts of duff burning during flaming phase on $\mathrm{PM}_{2.5}$ may be more remarkable in the southeastern US than many other world regions.

Duff consumption in different fire cases is highly variable, making it difficult to conduct practical operational prediction of duff consumption and the air quality impacts. A number of efforts could be made towards a solution. One is to map spatial distributions of duff. Fuel data such as the Fuel Characteristics Classification System (Prichard et al., 2019) could be expanded to include more complete duff information. The data need to be dynamical to reflect not only duff accumulation over time but also disturbance due to wildland fires. Another effort is to conduct more field measurements of duff consumption by both wildfires and prescribed fires, such as those by Zhao et al. (2019) and the Fire and Smoke Model Evaluation Experiment (FASMEE) (Prichard et al., 2019). The measurements are essential for developing tools for duff consumption and air quality impact modeling (Liu et al., 2019). Duff burning by flaming fires occurs mainly under persistent drought conditions. Thus, duff fuel moisture is a critically important parameter to predict if and how much duff will be consumed by a wildfire. There are fire danger rating systems such as the Canadian Forest Fire Weather Index (FWI) System (FWI) (Stocks et al., 1989) and FARSITE (Finney, 1998) that estimate duff fuel moisture. They are empirically based rather than physics based dynamical tools. Improvements to these tools and development of dynamical tools, including those that relate duff fuel moisture with drought indices such as the Keetch-Byram Drought Index (KBDI) (Keetch and Byram, 1968), are needed.

Under climate change due to the increasing atmospheric greenhouse gases, duff burning becomes more important for PM simulation and the air quality impacts. Duff burning is likely to become more active under the changing climate. The increasing frequency of extreme droughts has been observed in the US (Mazdiyasni and AghaKouchak, 2015; Clark et al., 2016) and around the world, and projected for the future climate scenario (Masih et al., 2014; Longo et al., 2018; Grillakis, 2019).

570 Therefore, fire events ignited on a generally wet land suffered by extreme drought are likely to happen more often in the future, and the duff and peat land that does not burn currently (e.g. the Amazon rainforests and Africa rainforests (Bonal et al., 2016)) may become burnable under future extreme drought. The importance of duff burning is further strengthened with climateecosystem interactions. With the increasing mean temperature and $\mathrm{CO}_{2}$ concentrations, the duff layer accumulation is potentially benefiting from the acceleration of vegetation growth (Qian et al., 2010; Huang et al., 2018; Lawal et al., 2019; Bai et al., 2020) and soil organic carbon decomposition (Fierer et al., 2006; Karhu et al., 2014). Besides, tropical peatland fires are sensitive to ENSO-induced climate variability, indicating that it is necessary to evaluate the fire-climate interactions in order to better understand the duff and peat burning (Field et al., 2009; Tosca et al., 2011).

Data availability. The EPA AQS measurement data of ozone and $\mathrm{PM}_{2.5}$ are available at the EPA website 580 (https://www.epa.gov/outdoor-air-quality-data, last access: October 22, 2020). The FINNv1.5 fire emission inventory is available at the NCAR ACOM website (https://bai.acom.ucar.edu/Data/fire/, last access: January 16, 2021). The MOZART 
simulation results used for simulation initial and boundary conditions are available at https://www.acom.ucar.edu/wrfchem/mozart.shtml, last access: January 16, 2021. The WRF-Chem model results are available from the corresponding author upon request.

Competing interests. The authors declare that they have no conflict of interest.

Author contribution. Yongqiang Liu provided the original idea. Aoxing Zhang and Yongqiang Liu designed the model experiments. Aoxing Zhang carried out the model experiments, analyzed the observation and simulation data and prepared the manuscript. Yongqiang Liu, Scott Goodrick and Marcus D Williams contributed to the methodology and manuscript improvement.

Acknowledgments. This study was supported by an agreement between the USDA Forest Service and the Oak Ridge Institute for Science and Education (ORISE).

\section{References}

Abatzoglou, J. T., and Williams, A. P.: Impact of anthropogenic climate change on wildfire across western US forests, Proceedings of the National Academy of Sciences, 113, 11770-11775, https://doi.org/10.1073/pnas.1607171113, 2016.

Akagi, S., Yokelson, R. J., Wiedinmyer, C., Alvarado, M., Reid, J., Karl, T., Crounse, J., and Wennberg, P.: Emission factors for open and domestic biomass burning for use in atmospheric models, Atmospheric Chemistry and Physics, 11, 4039-4072, https://doi.org/10.5194/acp-

\section{$600 \quad 11-4039-2011,2011$}

Alvarado, M., Logan, J., Mao, J., Apel, E., Riemer, D., Blake, D., Cohen, R., Min, K., Perring, A., and Browne, E.: Nitrogen oxides and PAN in plumes from boreal fires during ARCTAS-B and their impact on ozone: an integrated analysis of aircraft and satellite observations, Atmospheric Chemistry and Physics, 10, 9739-9760, https://doi.org/10.5194/acp-10-9739-2010, 2010.

Amiridis, V., Zerefos, C., Kazadzis, S., Gerasopoulos, E., Eleftheratos, K., Vrekoussis, M., Stohl, A., Mamouri, R.-E., Kokkalis, P., and

605 Papayannis, A.: Impact of the 2009 Attica wild fires on the air quality in urban Athens, Atmospheric Environment, 46, 536-544, https://doi.org/10.1016/j.atmosenv.2011.07.056, 2012.

Andreae, M. O., and Merlet, P.: Emission of trace gases and aerosols from biomass burning, Global biogeochemical cycles, 15, 955-966, https://doi.org/10.1029/2000GB001382, 2001.

Andreae, M. O.: Emission of trace gases and aerosols from biomass burning-an updated assessment, Atmospheric Chemistry and Physics,

610 19, 8523-8546, https://doi.org/10.5194/acp-19-8523-2019, 2019.

Astitha, M., Luo, H., Rao, S. T., Hogrefe, C., Mathur, R., and Kumar, N.: Dynamic evaluation of two decades of WRF-CMAQ ozone simulations over the contiguous United States, Atmospheric Environment, 164, 102-116, 2017.

Bachelet, D., Neilson, R. P., Lenihan, J. M., and Drapek, R. J.: Climate change effects on vegetation distribution and carbon budget in the United States, Ecosystems, 4, 164-185, https://doi.org/10.1007/s10021-001-0002-7, 2001.

615 Bai, Y., Guo, C., Degen, A. A., Ahmad, A. A., Wang, W., Zhang, T., Li, W., Ma, L., Huang, M., and Zeng, H.: Climate warming benefits alpine vegetation growth in Three-River Headwater Region, China, Science of the Total Environment, 742, 140574, https://doi.org/10.1016/j.scitotenv.2020.140574, 2020.

Ballhorn, U., Siegert, F., Mason, M., and Limin, S.: Derivation of burn scar depths and estimation of carbon emissions with LIDAR in Indonesian peatlands, Proceedings of the National Academy of Sciences, 106, 21213-21218, https://doi.org/10.1073/pnas.0906457106,

Barbero, R., Abatzoglou, J. T., Larkin, N. K., Kolden, C. A., and Stocks, B.: Climate change presents increased potential for very large fires in the contiguous United States, International Journal of Wildland Fire, 24, 892-899, https://doi.org/10.1071/WF15083, 2015.

Barnard, J. C., Fast, J. D., Paredes-Miranda, G., Arnott, W., and Laskin, A.: Evaluation of the WRF-Chem" Aerosol Chemical to Aerosol Optical Properties" Module using data from the MILAGRO campaign, Atmospheric Chemistry \& Physics, 10, https://doi.org/10.5194/acp-

Belda, M., Holtanová, E., Halenka, T., and Kalvová, J.: Climate classification revisited: from Köppen to Trewartha, Climate research, 59, 1-13, https://doi.org/10.3354/cr01204, 2014. 
Benner, W. H.: Photochemical reactions of forest fire combustion products, University of Florida, 1977.

Blood, A., Starr, G., Escobedo, F., Chappelka, A., and Staudhammer, C.: How do urban forests compare? Tree diversity in urban and periurban forests of the southeastern US, Forests, 7, 120, https://doi.org/10.3390/f7060120, 2016.

Bo, M., Mercalli, L., Pognant, F., Berro, D. C., and Clerico, M.: Urban air pollution, climate change and wildfires: The case study of an extended forest fire episode in northern Italy favoured by drought and warm weather conditions, Energy Reports, 6, 781-786, https://doi.org/10.1016/j.egyr.2019.11.002, 2020.

Bonal, D., Burban, B., Stahl, C., Wagner, F., and Hérault, B.: The response of tropical rainforests to drought-lessons from recent research 635 and future prospects, Annals of Forest Science, 73, 27-44, http://doi.org/10.1007/s13595-015-0522-5, 2016.

Bond, W. J., Woodward, F. I., and Midgley, G. F.: The global distribution of ecosystems in a world without fire, New phytologist, 165, 525538, https://doi.org/10.1111/j.1469-8137.2004.01252.x, 2005.

Borren, W., Bleuten, W., and Lapshina, E. D.: Holocene peat and carbon accumulation rates in the southern taiga of western Siberia, Quaternary Research, 61, 42-51, https://doi.org/10.1016/j.yqres.2003.09.002, 2004.

640 Bowman, D. M., Balch, J. K., Artaxo, P., Bond, W. J., Carlson, J. M., Cochrane, M. A., D’Antonio, C. M., DeFries, R. S., Doyle, J. C., and Harrison, S. P.: Fire in the Earth system, science, 324, 481-484, http://doi.org/10.1126/science.1163886, 2009.

Brey, S. J., and Fischer, E. V.: Smoke in the city: how often and where does smoke impact summertime ozone in the United States?, Environmental science \& technology, 50, 1288-1294, https://doi.org/10.1021/acs.est.5b05218, 2016.

Brown, T., Leach, S., Wachter, B., and Gardunio, B.: The Extreme 2018 Northern California Fire Season, Bulletin of the American

645 Meteorological Society, 101, S1-S4, https://doi.org/10.1175/BAMS-D-19-0275.1, 2020.

Chapman, E. G., Gustafson Jr, W., Easter, R. C., Barnard, J. C., Ghan, S. J., Pekour, M. S., and Fast, J. D.: Coupling aerosol-cloud-radiative processes in the WRF-Chem model: Investigating the radiative impact of elevated point sources, Atmospheric Chemistry \& Physics, 9 , https://doi.org/10.5194/acp-9-945-2009, 2009.

Chin, M., Ginoux, P., Kinne, S., Torres, O., Holben, B. N., Duncan, B. N., Martin, R. V., Logan, J. A., Higurashi, A., and Nakajima, T.:

650 Tropospheric aerosol optical thickness from the GOCART model and comparisons with satellite and Sun photometer measurements, Journal of the atmospheric sciences, 59, 461-483, https://doi.org/10.1175/1520-0469(2002)059<0461:TAOTFT>2.0.CO;2, 2002.

Clark, J. S., Iverson, L., Woodall, C. W., Allen, C. D., Bell, D. M., Bragg, D. C., D'Amato, A. W., Davis, F. W., Hersh, M. H., and Ibanez, I.: The impacts of increasing drought on forest dynamics, structure, and biodiversity in the United States, Global change biology, 22, 23292352, https://doi.org/10.1111/gcb.13160, 2016.

655 Crutzen, P. J., and Andreae, M. O.: Biomass burning in the tropics: Impact on atmospheric chemistry and biogeochemical cycles, Science, 250, 1669-1678, http://doi.org/10.1126/science.250.4988.1669, 1990.

Cuchiara, G. C., Rappenglück, B., Rubio, M. A., Lissi, E., Gramsch, E., and Garreaud, R. D.: Modeling study of biomass burning plumes and their impact on urban air quality; a case study of Santiago de Chile, Atmospheric Environment, 166, 79-91, https://doi.org/10.1016/j.atmosenv.2017.07.002, 2017.

660 Damian, V., Sandu, A., Damian, M., Potra, F., and Carmichael, G. R.: The kinetic preprocessor KPP-a software environment for solving chemical kinetics, Computers \& Chemical Engineering, 26, 1567-1579, https://doi.org/10.1016/S0098-1354(02)00128-X, 2002.

Darmenov, A., and da Silva, A.: The quick fire emissions dataset (QFED)-documentation of versions 2.1, 2.2 and 2.4, NASA Technical Report Series on Global Modeling and Data Assimilation, NASA TM-2013-104606, 32, 183, https://ntrs.nasa.gov/citations/20180005253, 2013.

665 Davies, G. M., Gray, A., Rein, G., and Legg, C. J.: Peat consumption and carbon loss due to smouldering wildfire in a temperate peatland, Forest Ecology and Management, 308, 169-177, https://doi.org/10.1016/j.foreco.2013.07.051, 2013.

Dennison, P. E., Brewer, S. C., Arnold, J. D., and Moritz, M. A.: Large wildfire trends in the western United States, 1984-2011, Geophysical Research Letters, 41, 2928-2933, https://doi.org/10.1002/2014GL059576, 2014.

Diehl, T., Heil, A., Chin, M., Pan, X., Streets, D., Schultz, M., and Kinne, S.: Anthropogenic, biomass burning, and volcanic emissions of

670 black carbon, organic carbon, and SO 2 from 1980 to 2010 for hindcast model experiments, Atmospheric Chemistry \& Physics Discussions, 12, https://doi.org/10.5194/acpd-12-24895-2012, 2012.

Eidenshink, J., Schwind, B., Brewer, K., Zhu, Z.-L., Quayle, B., and Howard, S.: A project for monitoring trends in burn severity, Fire ecology, 3, 3-21, 2007.

Ellison, L., Ichoku, C., Zhang, F., and Wang, J.: Building the Fire Energetics and Emissions Research (FEER) Smoke Emissions Inventory

675 Version 1.0, https://core.ac.uk/download/pdf/42724821.pdf, 2014.

Emmons, L. K., Walters, S., Hess, P. G., Lamarque, J.-F., Pfister, G. G., Fillmore, D., Granier, C., Guenther, A., Kinnison, D., and Laepple, T.: Description and evaluation of the Model for Ozone and Related chemical Tracers, version 4 (MOZART-4), http://doi.org/10.5194/gmd3-43-2010, 2010.

Fang, T., Verma, V., Bates, J. T., Abrams, J., Klein, M., Strickland, M. J., Sarnat, S. E., Chang, H. H., Mulholland, J. A., and Tolbert, P. E.:

680 Oxidative potential of ambient water-soluble PM2. 5 in the southeastern United States: contrasts in sources and health associations between ascorbic acid (AA) and dithiothreitol (DTT) assays, Atmos. Chem. Phys, 16, 3865-3879, https://doi.org/10.5194/acp-16-3865-2016, 2016. 
Fast, J. D., Gustafson Jr, W. I., Easter, R. C., Zaveri, R. A., Barnard, J. C., Chapman, E. G., Grell, G. A., and Peckham, S. E.: Evolution of ozone, particulates, and aerosol direct radiative forcing in the vicinity of Houston using a fully coupled meteorology-chemistry-aerosol model, Journal of Geophysical Research: Atmospheres, 111, https://doi.org/10.1029/2005JD006721, 2006.

685 Field, R. D., Van Der Werf, G. R., and Shen, S. S.: Human amplification of drought-induced biomass burning in Indonesia since 1960, Nature Geoscience, 2, 185-188, https://doi.org/10.1038/ngeo443, 2009.

Fierer, N., Colman, B. P., Schimel, J. P., and Jackson, R. B.: Predicting the temperature dependence of microbial respiration in soil: A continental-scale analysis, Global Biogeochemical Cycles, 20, https://doi.org/10.1029/2005GB002644, 2006.

Finco, M., Quayle, B., Zhang, Y., Lecker, J., Megown, K. A., and Brewer, C. K.: Monitoring trends and burn severity (MTBS): monitoring

690 wildfire activity for the past quarter century using Landsat data, In: Morin, Randall S.; Liknes, Greg C., comps. Moving from status to trends: Forest Inventory and Analysis (FIA) symposium 2012; 2012 December 4-6; Baltimore, MD. Gen. Tech. Rep. NRS-P-105. Newtown Square, PA: US Department of Agriculture, Forest Service, Northern Research Station.[CD-ROM]: 222-228., 2012, $222-228$.

Finney, M. A.: FARSITE, Fire Area Simulator--model development and evaluation, 4, US Department of Agriculture, Forest Service, Rocky Mountain Research Station, 1998.

695 Fire Behavior Assessment Team: Big Turnaround and Georgia Bay Complexes Fire Behavior Assessment Report, http://citeseerx.ist.psu.edu/viewdoc/download?doi=10.1.1.649.9331\&rep=rep1\&type=pdf, 2007.

FNL NCEP: NCEP FNL Operational Model Global Tropospheric Analyses, continuing from July 1999. , Research Data Archive at the National Center for Atmospheric Research; Computational and Information Systems Laboratory: Boulder, CO, USA, http://doi.org/10.5065/D6M043C6, 2000.

700 Frandsen, W. H.: The influence of moisture and mineral soil on the combustion limits of smoldering forest duff, Canadian Journal of Forest Research, 17, 1540-1544, https://doi.org/10.1139/x87-236, 1987.

Freitas, S. R., Longo, K. M., Chatfield, R., Latham, D., Silva Dias, M., Andreae, M., Prins, E., Santos, J., Gielow, R., and Carvalho Jr, J.: Including the sub-grid scale plume rise of vegetation fires in low resolution atmospheric transport models, Atmospheric Chemistry and Physics, 7, 3385-3398, https://doi.org/10.5194/acp-7-3385-2007, 2007.

705 Frolking, S., Roulet, N. T., Moore, T. R., Richard, P. J., Lavoie, M., and Muller, S. D.: Modeling northern peatland decomposition and peat accumulation, Ecosystems, 4, 479-498, https://doi.org/10.1007/s10021-001-0105-1, 2001.

Gaffen, D. J., and Ross, R. J.: Climatology and trends of US surface humidity and temperature, Journal of Climate, 12, 811-828, https://doi.org/10.1175/1520-0442(1999)012<0811:CATOUS>2.0.CO;2, 1999.

Geron, C., and Hays, M.: Air emissions from organic soil burning on the coastal plain of North Carolina, Atmospheric environment, 64,

710 192-199, https://doi.org/10.1016/j.atmosenv.2012.09.065, 2013.

Giglio, L., Randerson, J. T., and Werf, G. R.: Analysis of daily, monthly, and annual burned area using the fourth-generation global fire emissions database (GFED4), Journal of Geophysical Research: Biogeosciences, 118, 317-328, https://doi.org/10.1002/jgrg.20042, 2013.

Ginoux, P., Chin, M., Tegen, I., Prospero, J. M., Holben, B., Dubovik, O., and Lin, S. J.: Sources and distributions of dust aerosols simulated with the GOCART model, Journal of Geophysical Research: Atmospheres, 106, 20255-20273, https://doi.org/10.1029/2000JD000053, 2001.

715 Goode, J. G., Yokelson, R. J., Ward, D. E., Susott, R. A., Babbitt, R. E., Davies, M. A., and Hao, W. M.: Measurements of excess O3, CO2, $\mathrm{CO}, \mathrm{CH} 4, \mathrm{C} 2 \mathrm{H} 4, \mathrm{C} 2 \mathrm{H} 2, \mathrm{HCN}, \mathrm{NO}, \mathrm{NH} 3, \mathrm{HCOOH}, \mathrm{CH} 3 \mathrm{COOH}, \mathrm{HCHO}$, and $\mathrm{CH} 3 \mathrm{OH}$ in 1997 Alaskan biomass burning plumes by airborne Fourier transform infrared spectroscopy (AFTIR), Journal of Geophysical Research: Atmospheres, 105, 22147-22166, https://doi.org/10.1029/2000JD900287, 2000.

Goodrick, S. L., Achtemeier, G. L., Larkin, N. K., Liu, Y., and Strand, T. M.: Modelling smoke transport from wildland fires: a review,

720 International Journal of Wildland Fire, 22, 83-94, https://doi.org/10.1071/WF11116, 2013.

Gorham, E.: Northern peatlands: role in the carbon cycle and probable responses to climatic warming, Ecological applications, 1, 182-195, https://doi.org/10.2307/1941811, 1991.

Granier, C., Bessagnet, B., Bond, T., D’Angiola, A., van Der Gon, H. D., Frost, G. J., Heil, A., Kaiser, J. W., Kinne, S., and Klimont, Z.: Evolution of anthropogenic and biomass burning emissions of air pollutants at global and regional scales during the 1980-2010 period,

725 Climatic Change, 109, 163, https://doi.org/10.1007/s10584-011-0154-1, 2011.

Grell, G., Freitas, S., Stuefer, M., and Fast, J.: Inclusion of biomass burning in WRF-Chem: impact of wildfires on weather forecasts, Atmospheric Chemistry \& Physics, 11, https://doi.org/10.5194/acp-11-5289-2011, 2011.

Grell, G. A., Peckham, S. E., Schmitz, R., McKeen, S. A., Frost, G., Skamarock, W. C., and Eder, B.: Fully coupled "online" chemistry within the WRF model, Atmospheric Environment, 39, 6957-6975, https://doi.org/10.1016/j.atmosenv.2005.04.027, 2005.

730 Grillakis, M. G.: Increase in severe and extreme soil moisture droughts for Europe under climate change, Science of The Total Environment, 660, 1245-1255, https://doi.org/10.1016/j.scitotenv.2019.01.001, 2019.

Guan, S., Wong, D. C., Gao, Y., Zhang, T., and Pouliot, G.: Impact of wildfire on particulate matter in the southeastern United States in November 2016, Science of The Total Environment, 138354, https://doi.org/10.1016/j.scitotenv.2020.138354, 2020.

Guenther, C.: Estimates of global terrestrial isoprene emissions using MEGAN (Model of Emissions of Gases and Aerosols from Nature), Atmospheric Chemistry and Physics, 6, https://doi.org/10.5194/acp-6-3181-2006, 2006. 
Gustafson Jr, W. I., Chapman, E. G., Ghan, S. J., Easter, R. C., and Fast, J. D.: Impact on modeled cloud characteristics due to simplified treatment of uniform cloud condensation nuclei during NEAQS 2004, Geophysical Research Letters, 34, https://doi.org/10.1029/2007GL030021, 2007.

He, C., Miljevic, B., Crilley, L. R., Surawski, N. C., Bartsch, J., Salimi, F., Uhde, E., Schnelle-Kreis, J., Orasche, J., and Ristovski, Z.: Characterisation of the impact of open biomass burning on urban air quality in Brisbane, Australia, Environment international, 91, 230-242, https://doi.org/10.1016/j.envint.2016.02.030, 2016.

Hille, M. G., and Stephens, S. L.: Mixed conifer forest duff consumption during prescribed fires: tree crown impacts, Forest Science, 51, 417-424, https://doi.org/10.1093/forestscience/51.5.417, 2005.

Hodzic, A., Madronich, S., Bohn, B., Massie, S., Menut, L., and Wiedinmyer, C.: Wildfire particulate matter in Europe during summer 2003: meso-scale modeling of smoke emissions, transport and radiative effects, https://doi.org/10.5194/acp-7-4043-2007, 2007.

$\mathrm{Hu}$, Y., Fernandez-Anez, N., Smith, T. E., and Rein, G.: Review of emissions from smouldering peat fires and their contribution to regional haze episodes, International Journal of Wildland Fire, 27, 293-312, https://doi.org/10.1071/WF17084, 2018.

Huang, K., Xia, J., Wang, Y., Ahlström, A., Chen, J., Cook, R. B., Cui, E., Fang, Y., Fisher, J. B., and Huntzinger, D. N.: Enhanced peak growth of global vegetation and its key mechanisms, Nature ecology \& evolution, 2, 1897-1905, https://doi.org/10.1038/s41559-018-0714-

$750 \quad \underline{0}, 2018$.

Iacono, M. J., Delamere, J. S., Mlawer, E. J., Shephard, M. W., Clough, S. A., and Collins, W. D.: Radiative forcing by long-lived greenhouse gases: Calculations with the AER radiative transfer models, Journal of Geophysical Research: Atmospheres, 113, https://doi.org/10.1029/2008JD009944, 2008.

IPCC: Climate Change 2013: The Physical Science Basis. Contribution of Working Group I to the Fifth Assessment Report of the

755 Intergovernmental Panel on Climate Change, 1535 pp, in, Cambridge Univ. Press, Cambridge, UK, and New York, 2013.

Jaffe, D., Chand, D., Hafner, W., Westerling, A., and Spracklen, D.: Influence of fires on O3 concentrations in the western US, Environmental science \& technology, 42, 5885-5891, https://doi.org/10.1021/es800084k, 2008.

Jaffe, D. A., and Wigder, N. L.: Ozone production from wildfires: A critical review, Atmospheric Environment, 51, 1-10, https://doi.org/10.1016/j.atmosenv.2011.11.063, 2012.

760 Jiang, W., Leroy, S. A., Ogle, N., Chu, G., Wang, L., and Liu, J.: Natural and anthropogenic forest fires recorded in the Holocene pollen record from a Jinchuan peat bog, northeastern China, Palaeogeography, Palaeoclimatology, Palaeoecology, 261, 47-57, https://doi.org/10.1016/j.palaeo.2008.01.007, 2008.

Jiang, Y., Yang, X.-Q., Liu, X., Qian, Y., Zhang, K., Wang, M., Li, F., Wang, Y., and Lu, Z.: Impacts of wildfire aerosols on global energy budget and climate: The role of climate feedbacks, Journal of Climate, 33, 3351-3366, https://doi.org/10.1175/JCLI-D-19-0572.1, 2020.

765 Johnson, K. A., and Schmerfeld, J.: THE UNITED STATES'NATIONAL WILDLIFE REFUGE SYSTEM: A NATURAL LABORATORY FOR STUDYING PEATLAND CARBON STORAGE, ECOSYSTEM SERVICES, AND IMPACTS OF MANAGEMENT, 15TH INTERNATIONAL PEAT CONGRESS 2016 https://peatlands.org/assets/uploads/2019/06/ipc16p696-700a253johnson.schmerfeld.pdf, 2016.

Jolly, W. M., Cochrane, M. A., Freeborn, P. H., Holden, Z. A., Brown, T. J., Williamson, G. J., and Bowman, D. M.: Climate-induced

770 variations in global wildfire danger from 1979 to 2013, Nature communications, 6, 7537, https://doi.org/10.1038/ncomms8537, 2015.

Kaiser, J., Flemming, J., Schultz, M., Suttie, M., and Wooster, M.: The MACC Global Fire Assimilation System: First Emission Products (GFASvO), ECMWF, 2009.

Kaiser, J., Heil, A., Andreae, M., Benedetti, A., Chubarova, N., Jones, L., Morcrette, J.-J., Razinger, M., Schultz, M., and Suttie, M.: Biomass burning emissions estimated with a global fire assimilation system based on observed fire radiative power, Biogeosciences, 9, 527,

775 https://doi.org/10.5194/bg-9-527-2012, 2012.

Karhu, K., Auffret, M. D., Dungait, J. A., Hopkins, D. W., Prosser, J. I., Singh, B. K., Subke, J.-A., Wookey, P. A., Ågren, G. I., and Sebastia, M.-T.: Temperature sensitivity of soil respiration rates enhanced by microbial community response, Nature, 513, 81-84, https://doi.org/10.1038/nature13604, 2014.

Keetch, J. J., and Byram, G. M.: A drought index for forest fire control, US Department of Agriculture, Forest Service, Southeastern Forest

780 Experiment ..., 1968.

Kiely, L., Spracklen, D. V., Wiedinmyer, C., Conibear, L., Reddington, C. L., Archer-Nicholls, S., Lowe, D., Arnold, S. R., Knote, C., and Khan, M. F.: New estimate of particulate emissions from Indonesian peat fires in 2015, http://doi.org/10.5194/acp-19-11105-2019, 2019.

Kiely, L., Spracklen, D. V., Wiedinmyer, C., Conibear, L. A., Reddington, C. L., Arnold, S. R., Knote, C., Khan, M. F., Latif, M. T., and Syaufina, L.: Air quality and health impacts of vegetation and peat fires in Equatorial Asia during 2004-2015, Environmental Research 785 Letters, https://doi.org/10.1088/1748-9326/ab9a6c, 2020.

Konrad, C. E., and Knox, P.: The Southeastern Drought and wildfire of 2016, Available at http://www.sercc.com/NIDISDroughtAssessmentFINAL.pdf [Verified 29 October 2020], 2017.

Kunzli, N., Avol, E., Wu, J., Gauderman, W. J., Rappaport, E., Millstein, J., Bennion, J., McConnell, R., Gilliland, F. D., and Berhane, K.: Health effects of the 2003 Southern California wildfires on children, American journal of respiratory and critical care medicine, 174, 1221- 
Lawal, S., Lennard, C., and Hewitson, B.: Response of southern African vegetation to climate change at 1.5 and $2.0^{\circ}$ global warming above the pre-industrial level, Climate Services, 16, 100134, https://doi.org/10.1016/j.cliser.2019.100134, 2019.

Li, W., Li, L., Fu, R., Deng, Y., and Wang, H.: Changes to the North Atlantic subtropical high and its role in the intensification of summer rainfall variability in the southeastern United States, Journal of Climate, 24, 1499-1506, https://doi.org/10.1175/2010JCLI3829.1, 2011.

795 Li, X., and Rappenglueck, B.: A study of model nighttime ozone bias in air quality modeling, Atmospheric Environment, 195, 210-228, https://doi.org/10.1016/j.atmosenv.2018.09.046, 2018.

Liu, J., Lin, P., Laskin, A., Laskin, J., Kathmann, S. M., Wise, M., Caylor, R., Imholt, F., Selimovic, V., and Shilling, J. E.: Optical properties and aging of light-absorbing secondary organic aerosol, Atmospheric Chemistry and Physics, 16, 12815-12827, https://doi.org/10.5194/acp16-12815-2016, 2016.

800 Liu, T., Mickley, L. J., Marlier, M. E., DeFries, R. S., Khan, M. F., Latif, M. T., and Karambelas, A.: Diagnosing spatial biases and uncertainties in global fire emissions inventories: Indonesia as regional case study, Remote Sensing of Environment, 237, 111557, https://doi.org/10.1016/j.rse.2019.111557, 2020.

Liu, Y., Goodrick, S., and Heilman, W.: Wildland fire emissions, carbon, and climate: Wildfire-climate interactions, Forest Ecology and Management, 317, 80-96, https://doi.org/10.1016/j.foreco.2013.02.020, 2014.

805 Liu, Y., Kochanski, A., Baker, K. R., Mell, W., Linn, R., Paugam, R., Mandel, J., Fournier, A., Jenkins, M. A., and Goodrick, S. et al.: Fire behaviour and smoke modelling: model improvement and measurement needs for next-generation smoke research and forecasting systems, International journal of wildland fire, 28, 570-588, 2019.

Longo, M., Knox, R. G., Levine, N. M., Alves, L. F., Bonal, D., Camargo, P. B., Fitzjarrald, D. R., Hayek, M. N., Restrepo-Coupe, N., and Saleska, S. R.: Ecosystem heterogeneity and diversity mitigate Amazon forest resilience to frequent extreme droughts, New Phytologist,

810 219, 914-931, https://doi.org/10.1111/nph.15185, 2018.

Lu, X., Zhang, L., Yue, X., Zhang, J., Jaffe, D. A., Stohl, A., Zhao, Y., and Shao, J.: Wildfire influences on the variability and trend of summer surface ozone in the mountainous western United States, https://doi.org/10.5194/acp-16-14687-2016, 2016.

Lu, Z., and Sokolik, I. N.: Examining the Impact of Smoke on Frontal Clouds and Precipitation During the 2002 Yakutsk Wildfires Using the WRF-Chem-SMOKE Model and Satellite Data, Journal of Geophysical Research: Atmospheres, 122, 12,765-712,785,

815 https://doi.org/10.1002/2017JD027001, 2017.

Madronich, S.: Photodissociation in the atmosphere: 1. Actinic flux and the effects of ground reflections and clouds, Journal of Geophysical Research: Atmospheres, 92, 9740-9752, https://doi.org/10.1029/JD092iD08p09740, 1987.

Mallia, D., Lin, J., Urbanski, S., Ehleringer, J., and Nehrkorn, T.: Impacts of upwind wildfire emissions on CO, CO2, and PM2. 5 concentrations in Salt Lake City, Utah, Journal of Geophysical Research: Atmospheres, 120, 147-166,

820 https://doi.org/10.1002/2014JD022472, 2015.

Mar, K. A., Ojha, N., Pozzer, A., and Butler, T. M.: Ozone air quality simulations with WRF-Chem (v3. 5.1) over Europe: model evaluation and chemical mechanism comparison, Geoscientific Model Development, 9, 3699-3728, 2016.

Masih, I., Maskey, S., Mussá, F., and Trambauer, P.: A review of droughts on the African continent: a geospatial and long-term perspective, Hydrology and Earth System Sciences, 18, 3635, https://doi.org/10.5194/hess-18-3635-2014, 2014.

825 Mass, C. F., and Ovens, D.: The Northern California wildfires of 8-9 October 2017: The role of a major downslope wind event, Bulletin of the American Meteorological Society, 100, 235-256, https://doi.org/10.1175/BAMS-D-18-0037.1, 2019.

Mazdiyasni, O., and AghaKouchak, A.: Substantial increase in concurrent droughts and heatwaves in the United States, Proceedings of the National Academy of Sciences, 112, 11484-11489, https://doi.org/10.1073/pnas.1422945112, 2015.

McDowell, I., Pierce, T., Pouliot, G., Eder, B., Foley, K., Gilliam, R., and Wilkins, J.: PM2.5 concentrations observed and modeled for the

8302016 southern Appalachian wildfire event, 16th Annual CMAS https://cfpub.epa.gov/si/si_public_record_report.cfm?dirEntryId=338093\&Lab=NERL, 2017.

McKee, D.: Tropospheric ozone: human health and agricultural impacts, CRC Press, 1993.

McMahon, C. K., Wade, D. D., and Tsoukalas, S. N.: Combustion characteristics and emissions from burning organic soils, In: 73rd Annual Meeting of the Air Pollution Control Association. Montreal, Quebec: June 22-27, 1980. 2-16., 1980, 2-16.

835 Milner, A. M., Baird, A. J., Green, S. M., Swindles, G. T., Young, D. M., Sanderson, N. K., Timmins, M. S., and Gałka, M.: A regime shift from erosion to carbon accumulation in a temperate northern peatland, Journal of Ecology, https://doi.org/10.1111/1365-2745.13453, 2020. Mlawer, E. J., Taubman, S. J., Brown, P. D., Iacono, M. J., and Clough, S. A.: Radiative transfer for inhomogeneous atmospheres: RRTM, a validated correlated-k model for the longwave, Journal of Geophysical Research: Atmospheres, 102, 16663-16682, https://doi.org/10.1029/97JD00237, 1997.

840 Navarro, K. M., Cisneros, R., O’Neill, S. M., Schweizer, D., Larkin, N. K., and Balmes, J. R.: Air-quality impacts and intake fraction of PM2. 5 during the 2013 Rim Megafire, Environmental Science \& Technology, 50, 11965-11973, https://doi.org/10.1021/acs.est.6b02252, 2016.

Noble, C. A., Vanderpool, R. W., Peters, T. M., McElroy, F. F., Gemmill, D. B., and Wiener, R. W.: Federal reference and equivalent methods for measuring fine particulate matter, Aerosol science \& technology, 34, 457-464, https://doi.org/10.1080/02786820121582, 2001. 
845 Ottmar, R., and Andreu, A.: Litter and duff bulk densities in the Southern United States, Seattle, WA: Fire and Environmental Applications team, USDA Forest Service, Joint Fire Science Program Project, 04-02, https://www.firescience.gov/projects/04-2-1-49/project/04-2-149 final_report.pdf, 2007.

Ottmar, R. D.: Wildland fire emissions, carbon, and climate: modeling fuel consumption, Forest Ecology and Management, 317, 41-50, https://doi.org/10.1016/j.foreco.2013.06.010, 2014.

850 Ovenden, L.: Peat accumulation in northern wetlands, Quaternary research, 33, 377-386, https://doi.org/10.1016/0033-5894(90)90063-Q, 1990.

Page, S. E., Siegert, F., Rieley, J. O., Boehm, H.-D. V., Jaya, A., and Limin, S.: The amount of carbon released from peat and forest fires in Indonesia during 1997, Nature, 420, 61-65, https://doi.org/10.1038/nature01131, 2002.

Page, S. E., Banks, C. J., and Rieley, J. O.: Tropical peatlands: distribution, extent and carbon storage-uncertainties and knowledge gaps, Peatlands International, 26-27, https://www.researchgate.net/profile/Susan Page/publication/239531431 Tropical peatlands Distribution extent and carbon storageuncertainties_and_knowledge_gaps/links/0046352976c99c75d3000000.pdf, 2007.

Pan, X., Ichoku, C., Chin, M., Bian, H., Darmenov, A., Colarco, P., Ellison, L., Kucsera, T., da Silva, A., and Wang, J.: Six global biomass burning emission datasets: intercomparison and application in one global aerosol model, Atmospheric Chemistry and Physics, 20, 969-994, 860 https://doi.org/10.5194/acp-20-969-2020, 2020.

Park Williams, A., Cook, B. I., Smerdon, J. E., Bishop, D. A., Seager, R., and Mankin, J. S.: The 2016 southeastern US drought: An extreme departure from centennial wetting and cooling, Journal of Geophysical Research: Atmospheres, 122, 10,888-810,905, https://doi.org/10.1002/2017JD027523, 2017.

Peckham, S., Grell, G., McKeen, S., Schmitz, R., Salzmann, M., Freitas, S., Fast, J., Gustafson, W., Ghan, S., and Zaveri, R.: WRF-Chem

865 Version 3.9. 1.1 User's Guide, 2018.

Pfister, G., Avise, J., Wiedinmyer, C., Edwards, D., Emmons, L., Diskin, G., Podolske, J., and Wisthaler, A.: CO source contribution analy sis for California during ARCTAS-CARB, Atmospheric Chemistry and Physics, 11, 7515, https://doi.org/10.5194/acp-11-7515-2011, 2011a.

Pfister, G., Parrish, D., Worden, H., Emmons, L., Edwards, D., Wiedinmyer, C., Diskin, G., Huey, G., Oltmans, S., and Thouret, V.: Characterizing summertime chemical boundary conditions for airmasses entering the US West Coast, Atmospheric Chemistry and Physics,

870 11, 1769, https://doi.org/10.5194/acp-11-1769-2011, 2011 b.

Pouliot, G., Gilliam, R., Eder, B., McDowell, I., Wilkins, J., and Pierce, T.: Evaluating the Wildfire Emission estimates in an Air Quality Simulation of the 2016 Southeastern United States Wildfires, International Emissions Inventory Conference, 2017.

Poulter, B., Christensen Jr, N. L., and Halpin, P. N.: Carbon emissions from a temperate peat fire and its relevance to interannual variability of trace atmospheric greenhouse gases, Journal of Geophysical Research: Atmospheres, 111, https://doi.org/10.1029/2005JD006455, 2006.

875 Powers, J. G., Klemp, J. B., Skamarock, W. C., Davis, C. A., Dudhia, J., Gill, D. O., Coen, J. L., Gochis, D. J., Ahmadov, R., and Peckham, S. E.: The weather research and forecasting model: Overview, system efforts, and future directions, Bulletin of the American Meteorological Society, 98, 1717-1737, https://doi.org/10.1175/BAMS-D-15-00308.1, 2017.

Prichard, S. J., Andreu, A. G., Ottmar, R. D., and Eberhardt, E.: Fuel Characteristic Classification System (FCCS) field sampling and fuelbed development guide, Gen. Tech. Rep. PNW-GTR-972. Portland, OR: US Department of Agriculture, Forest Service, Pacific Northwest

880 Research Station. 77 p., 972, 2019.

Qian, S., Fu, Y., and Pan, F.: Climate change tendency and grassland vegetation response during the growth season in Three-River Source Region, Science China Earth Sciences, 53, 1506-1512, http://doi.org/10.1007/s11430-010-4064-2, 2010.

Raaflaub, L., and Valeo, C.: Hydrological properties of duff, Water resources research, 45, https://doi.org/10.1029/2008WR007396, 2009.

Randerson, J., Chen, Y., Werf, G., Rogers, B., and Morton, D.: Global burned area and biomass burning emissions from small fires, Journal

885 of Geophysical Research: Biogeosciences, 117, https://doi.org/10.1029/2012JG002128, 2012.

Reddington, C. L., Morgan, W. T., Darbyshire, E., Brito, J., Coe, H., Artaxo, P., Scott, C. E., Marsham, J., and Spracklen, D. V.: Biomass burning aerosol over the Amazon: analysis of aircraft, surface and satellite observations using a global aerosol model, Atmospheric Chemistry and Physics, https://doi.org/10.5194/acp-19-9125-2019, 2019.

Reddy, A. D., Hawbaker, T. J., Wurster, F., Zhu, Z., Ward, S., Newcomb, D., and Murray, R.: Quantifying soil carbon loss and uncertainty

890 from a peatland wildfire using multi-temporal LiDAR, Remote Sensing of Environment, 170, 306-316, https://doi.org/10.1016/j.rse.2015.09.017, 2015.

Reid, C. E., Brauer, M., Johnston, F. H., Jerrett, M., Balmes, J. R., and Elliott, C. T.: Critical review of health impacts of wildfire smoke exposure, Environmental health perspectives, 124, 1334-1343, https://doi.org/10.1289/ehp.1409277, 2016.

Rein, G.: Smoldering combustion phenomena and coal fires, Coal and Peat Fires: A Global Perspective: Coal—Geology and Combustion,

895 1, 307-315, http://doi.org/10.1016/B978-0-444-52858-2.00017-7, 2011.

Rein, G., and Belcher, C.: Smouldering fires and natural fuels, Fire phenomena and the Earth system: an interdisciplinary guide to fire science, 15-33, https://doi.org/10.1002/9781118529539.ch2, 2013.

Roulston, C., Paton-Walsh, C., Smith, T., Guérette, É. A., Evers, S., Yule, C. M., Rein, G., and Van der Werf, G.: Fine particle emissions from tropical peat fires decrease rapidly with time since ignition, Journal of Geophysical Research: Atmospheres, 123, 5607-5617, 
Sakulyanontvittaya, T., Duhl, T., Wiedinmyer, C., Helmig, D., Matsunaga, S., Potosnak, M., Milford, J., and Guenther, A.: Monoterpene and sesquiterpene emission estimates for the United States, Environmental science \& technology, 42, 1623-1629, https://doi.org/10.1021/es702274e, 2008.

San Jose, R., Pérez, J., González, R., Pecci, J., and Palacios, M.: Improving air quality modelling systems by using on-line wild land fire 905 forecasting tools coupled into WRF/Chem simulations over Europe, Urban climate, 22, 2-18, https://doi.org/10.1016/j.uclim.2016.09.001, 2017.

Sandu, A., Daescu, D. N., and Carmichael, G. R.: Direct and adjoint sensitivity analysis of chemical kinetic systems with KPP: Part Itheory and software tools, Atmospheric Environment, 37, 5083-5096, https://doi.org/10.1016/j.atmosenv.2003.08.019, 2003.

Sandu, A., and Sander, R.: Simulating chemical systems in Fortran90 and Matlab with the Kinetic PreProcessor KPP-2.1, Atmospheric

910 Chemistry and Physics, 6, 187-195, https://doi.org/10.5194/acp-6-187-2006, 2006.

Seinfeld, J. H., and Pandis, S. N.: Atmospheric chemistry and physics: from air pollution to climate change, John Wiley \& Sons, 2016.

Selimovic, V., Yokelson, R. J., McMeeking, G. R., and Coefield, S.: Aerosol mass and optical properties, smoke influence on O3, and high NO3 production rates in a western US city impacted by wildfires, Journal of Geophysical Research: Atmospheres, 125, e2020JD032791, 2020.

915 Shaposhnikov, D., Revich, B., Bellander, T., Bedada, G. B., Bottai, M., Kharkova, T., Kvasha, E., Lezina, E., Lind, T., and Semutnikova, E.: Mortality related to air pollution with the Moscow heat wave and wildfire of 2010, Epidemiology (Cambridge, Mass.), 25, 359, http://doi.org/10.1097/EDE.0000000000000090, 2014.

Singh, H., Cai, C., Kaduwela, A., Weinheimer, A., and Wisthaler, A.: Interactions of fire emissions and urban pollution over California: Ozone formation and air quality simulations, Atmospheric Environment, 56, 45-51, https://doi.org/10.1016/j.atmosenv.2012.03.046, 2012.

920 Southern Appalachian Man and the Biosphere: The Southern Appalachian assessment summary report, in, US Department of Agriculture Washington, DC, 1996.

Stauffer, D. R., and Seaman, N. L.: Use of four-dimensional data assimilation in a limited-area mesoscale model. Part I: Experiments with synoptic-scale data, Monthly Weather Review, 118, 1250-1277, https://doi.org/10.1175/1520-0493(1990)118<1250:UOFDDA>2.0.CO;2, 1990.

925 Stocks, B. J., Lynham, T., Lawson, B., Alexander, M., Wagner, C. V., McAlpine, R., and Dube, D.: Canadian forest fire danger rating system: an overview, The Forestry Chronicle, 65, 258-265, 1989.

Tansey, K., Beston, J., Hoscilo, A., Page, S., and Paredes Hernández, C.: Relationship between MODIS fire hot spot count and burned area in a degraded tropical peat swamp forest in Central Kalimantan, Indonesia, Journal of Geophysical Research: Atmospheres, 113, https://doi.org/10.1029/2008JD010717, 2008.

930 Thompson, G., Field, P. R., Rasmussen, R. M., and Hall, W. D.: Explicit forecasts of winter precipitation using an improved bulk microphysics scheme. Part II: Implementation of a new snow parameterization, Monthly Weather Review, 136, 5095-5115, https://doi.org/10.1175/2008MWR2387.1, 2008.

Tosca, M., Randerson, J., Zender, C., Nelson, D., Diner, D., and Logan, J.: Dynamics of fire plumes and smoke clouds associated with peat and deforestation fires in Indonesia, Journal of Geophysical Research: Atmospheres, 116, https://doi.org/10.1029/2010JD015148, 2011.

935 Tosca, M., Randerson, J., and Zender, C.: Global impact of smoke aerosols from landscape fires on climate and the Hadley circulation, Atmospheric Chemistry and Physics, 13, 5227-5241, https://doi.org/10.5194/acp-13-5227-2013, 2013.

Turetsky, M. R., Benscoter, B., Page, S., Rein, G., Van Der Werf, G. R., and Watts, A.: Global vulnerability of peatlands to fire and carbon loss, Nature Geoscience, 8, 11-14, https://doi.org/10.1038/ngeo2325, 2015.

Urbanski, S.: Wildland fire emissions, carbon, and climate: Emission factors, Forest Ecology and Management, 317, 51-60,

940 https://doi.org/10.1016/j.foreco.2013.05.045, 2014.

USEPA: Profile of version 1 of the 2014 national emissions inventory, https://www.epa.gov/sites/production/files/201704/documents/2014neiv1 profile final april182017.pdf, 2017.

USEPA: EPA's 2014 National Air Toxics Assessment (Technical Support Document). , U.S. Environmental Protection Agency, Research Triangle Park, North Carolina. url: https://www.epa.gov/national-air-toxics-assessment/2014-nata-technical-support-document, 2018a.

945 USEPA: Preparation of Emissions Inventories for the Version 7.1 2014 Emissions Modeling Platform for the National Air Toxics Assessment (Technical Support Document). U.S., Environmental Protection Agency, Research Triangle Park, North Carolina. url: https://www.epa.gov/air-emissions-modeling/2014-version-71-platform, 2018b.

Van Der Werf, G. R., Randerson, J. T., Giglio, L., Van Leeuwen, T. T., Chen, Y., Rogers, B. M., Mu, M., Van Marle, M. J., Morton, D. C., and Collatz, G. J.: Global fire emissions estimates during 1997-2016, Earth System Science Data, 9, 697-720, https://doi.org/10.5194/essd-

950 9-697-2017, 2017.

Verma, V., Fang, T., Guo, H., King, L., Bates, J., Peltier, R., Edgerton, E., Russell, A., and Weber, R.: Reactive oxygen species associated with water-soluble PM 2.5 in the southeastern United States: spatiotemporal trends and source apportionment, Atmospheric Chemistry \& Physics Discussions, 14, https://doi.org/10.5194/acp-14-12915-2014, 2014.

Wang, K., Zhang, Y., Yahya, K., Wu, S.-Y., and Grell, G.: Implementation and initial application of new chemistry-aerosol options in

$955 \mathrm{WRF} / \mathrm{Chem}$ for simulating secondary organic aerosols and aerosol indirect effects for regional air quality, Atmospheric Environment, 115, 716-732, https://doi.org/10.1016/j.atmosenv.2014.12.007, 2015. 
Ward, D. S., Kloster, S., Mahowald, N. M., Rogers, B. M., Randerson, J. T., and Hess, P. G.: The changing radiative forcing of fires: global model estimates for past, present and future, Atmospheric Chemistry and Physics, 12, 10857-10886, 10.5194/acp-12-10857-2012, 2012.

Watts, A. C., and Kobziar, L. N.: Smoldering Combustion in Organic Soils: Peat and Muck Fires in the Southeastern US, SFE Research

960 Synthesis, 1-5, https://www.firescience.gov/projects/11-3-1-22/project/11-3-1-22_SFE_Synthesis_Smoldering_2012-9.pdf, 2012.

Watts, A. C.: Organic soil combustion in cypress swamps: moisture effects and landscape implications for carbon release, Forest Ecology and Management, 294, 178-187, https://doi.org/10.1016/j.foreco.2012.07.032, 2013.

Wieder, R. K., Vitt, D. H., and Benscoter, B. W.: Peatlands and the boreal forest, in: Boreal peatland ecosystems, Springer, 1-8, 2006.

Wiedinmyer, C., Quayle, B., Geron, C., Belote, A., McKenzie, D., Zhang, X., O’Neill, S., and Wynne, K. K.: Estimating emissions from

965 fires in North America for air quality modeling, Atmospheric Environment, 40, 3419-3432, https://doi.org/10.1016/j.atmosenv.2006.02.010, 2006.

Wiedinmyer, C., Akagi, S., Yokelson, R. J., Emmons, L., Al-Saadi, J., Orlando, J., and Soja, A.: The Fire INventory from NCAR (FINN): A high resolution global model to estimate the emissions from open burning, Geoscientific Model Development, 4, 625, https://doi.org/10.5194/gmd-4-625-2011, 2011.

970 Wilbur, R. B., and Christensen, N. L.: Effects of fire on nutrient availability in a North Carolina coastal plain pocosin, American Midland Naturalist, 54-61, https://doi.org/10.2307/2425213, 1983.

Wilkins, J. L., Pouliot, G., Foley, K., Appel, W., and Pierce, T.: The impact of US wildland fires on ozone and particulate matter: a comparison of measurements and CMAQ model predictions from 2008 to 2012, International Journal of Wildland Fire, 27, 684-698, https://doi.org/10.1071/WF18053, 2018.

975 Yang, A., Janssen, N. A., Brunekreef, B., Cassee, F. R., Hoek, G., and Gehring, U.: Children's respiratory health and oxidative potential of PM2. 5: the PIAMA birth cohort study, Occupational and Environmental Medicine, 73, 154-160, http://dx.doi.org/10.1136/oemed-2015$\underline{103175,2016 .}$

Yang, G., Di, X.-y., Guo, Q.-X., Shu, Z., Zeng, T., Yu, H.-z., and Wang, C.: The impact of climate change on forest fire danger rating in China's boreal forest, Journal of Forestry Research, 22, 249-257, https://doi.org/10.1007/s11676-011-0158-8, 2011.

980 Yokelson, R. J., Burling, I., Gilman, J., Warneke, C., Stockwell, C., Gouw, J. d., Akagi, S., Urbanski, S., Veres, P., and Roberts, J.: Coupling field and laboratory measurements to estimate the emission factors of identified and unidentified trace gases for prescribed fires, Atmospheric Chemistry and Physics, 13, 89-116, 2013.

Yu, J.-Y., Kao, H.-Y., and Lee, T.: Subtropics-related interannual sea surface temperature variability in the central equatorial Pacific, Journal of Climate, 23, 2869-2884, https://doi.org/10.1175/2010JCLI3171.1, 2010.

985 Yue, X., and Unger, N.: Fire air pollution reduces global terrestrial productivity, Nature communications, 9, 1-9, https://doi.org/10.1038/s41467-018-07921-4, 2018.

Zhang, A., Wang, Y., Zhang, Y., Weber, R. J., Song, Y., Ke, Z., and Zou, Y.: Modeling the global radiative effect of brown carbon: a potentially larger heating source in the tropical free troposphere than black carbon, Atmos. Chem. Phys., 20, 1901-1920, https://doi.org/10.5194/acp-20-1901-2020, 2020.

990 Zhang, L., Wang, T., Zhang, Q., Zheng, J., Xu, Z., and Lv, M.: Potential sources of nitrous acid (HONO) and their impacts on ozone: A WRF-Chem study in a polluted subtropical region, Journal of Geophysical Research: Atmospheres, 121, 3645-3662, https://doi.org/10.1002/2015JD024468, 2016.

Zhang, Y., and Wang, Y.: Climate-driven ground-level ozone extreme in the fall over the Southeast United States, Proceedings of the National Academy of Sciences, 113, 10025-10030, https://doi.org/10.1073/pnas.1602563113, 2016.

995 Zhao, F., Liu, Y., Goodrick, S., Hornsby, B., and Schardt, J.: The contribution of duff consumption to fire emissions and air pollution of the Rough Ridge Fire, International Journal of Wildland Fire, 28, 993-1004, https://doi.org/10.1071/WF18205, 2019.

Zhu, Z., and Evans, D. L.: US forest types and predicted percent forest cover from AVHRR data, PE \& RS- Photogrammetric Engineering \& Remote Sensing, 60, 525-531, https://www.asprs.org/wp-content/uploads/pers/1994journal/may/1994 may 525-531.pdf, 1994.

Zou, Y., Wang, Y., Qian, Y., Tian, H., Yang, J., and Alvarado, E.: Using CESM-RESFire to understand climate-fire-ecosystem interactions and the implications for decadal climate variability, Atmospheric Chemistry and Physics, 20, https://doi.org/10.5194/acp-20-995-2020, 2020. 


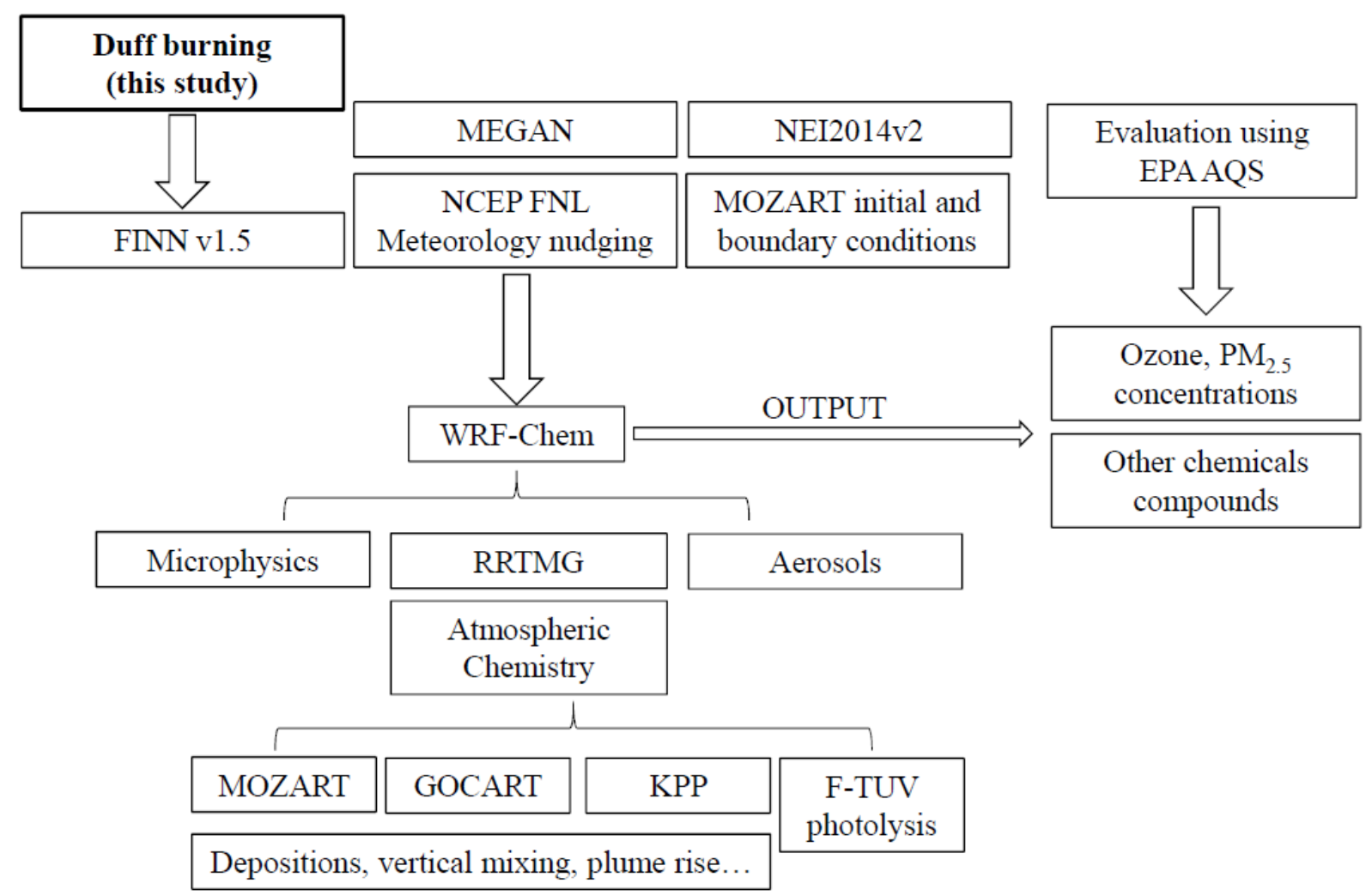

Figure 1. Description of the model components, input data, and implementation procedures.

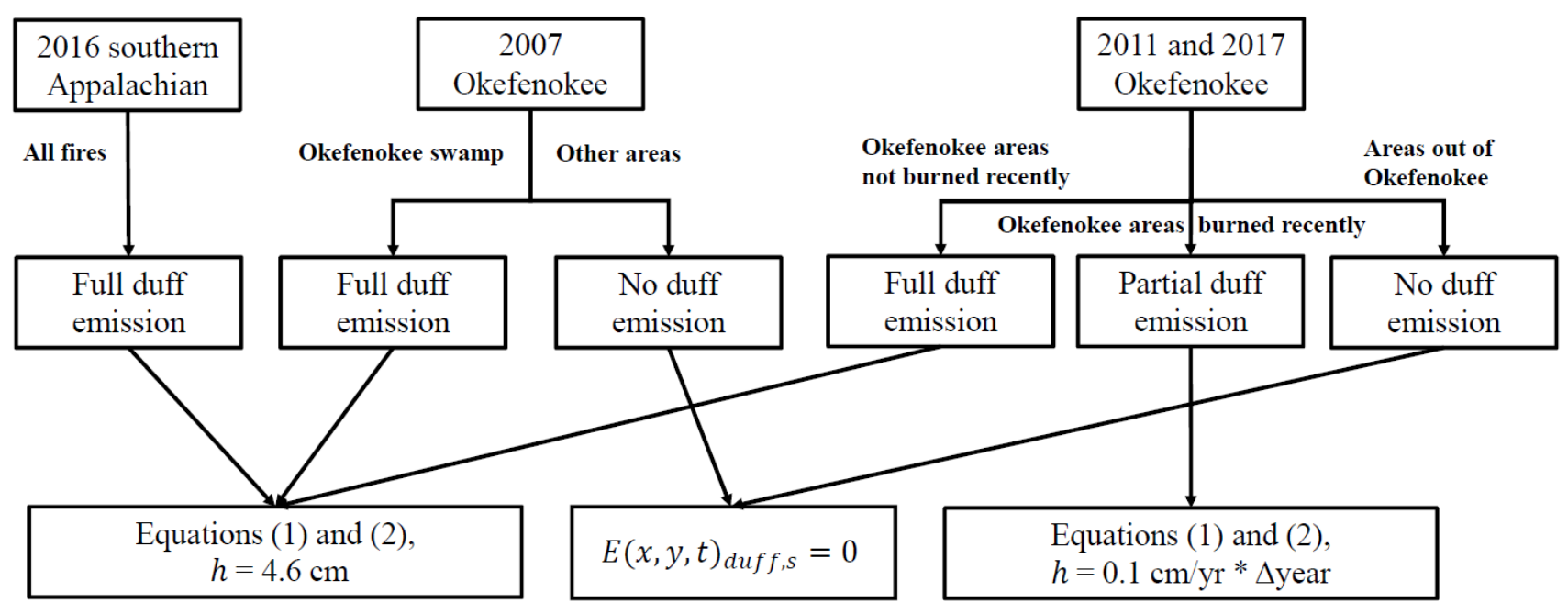

Figure 2. Description of the duff emission estimation. 
(a) 2016 southern Appalachian
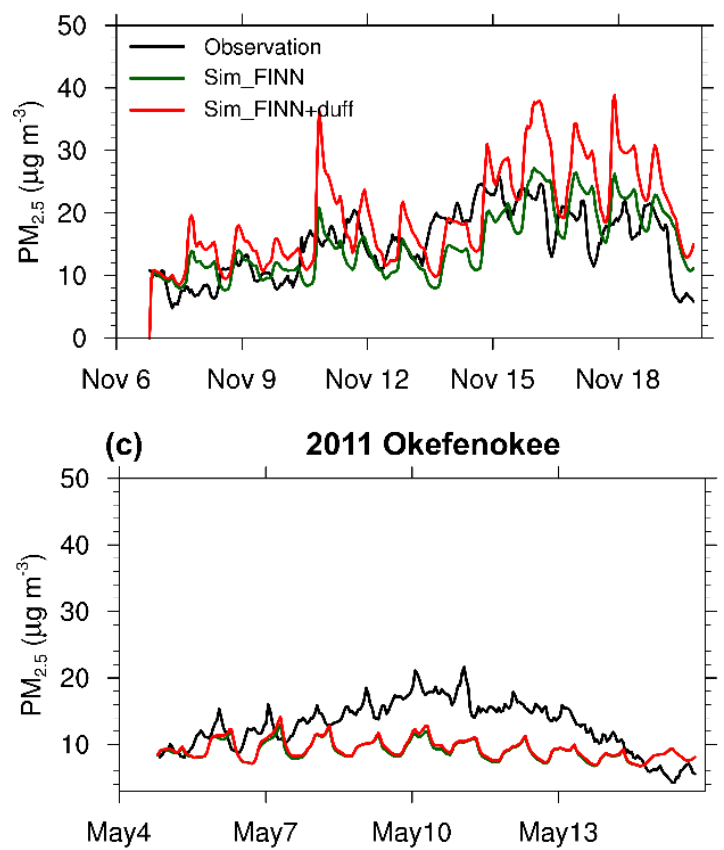

(b)

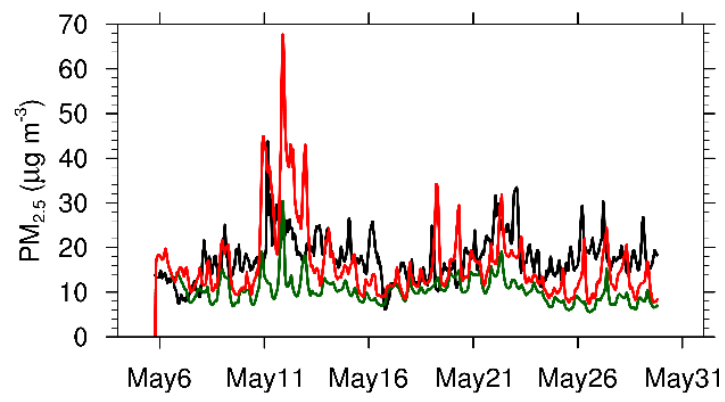

(d)

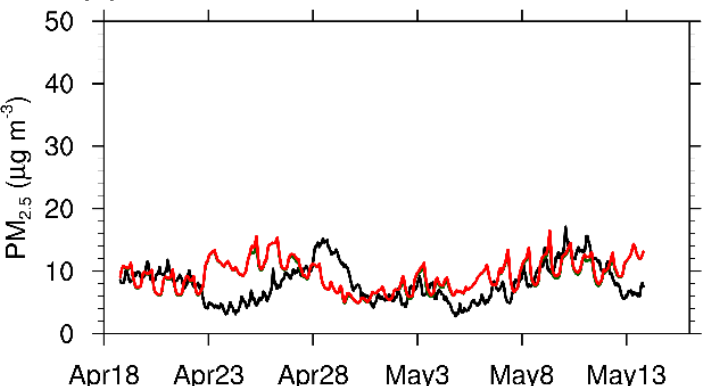

1010 Figure 3. The time series of hourly surface $\mathbf{P M}_{2.5}$ concentrations. Black: Measurements averaged over observation sites within the simulation domain. Green and red: Simulations of Sim_FINN and Sim_FINN+duff, respectively, averaged over the observation sites.

(a) 2016 southern Appalachian

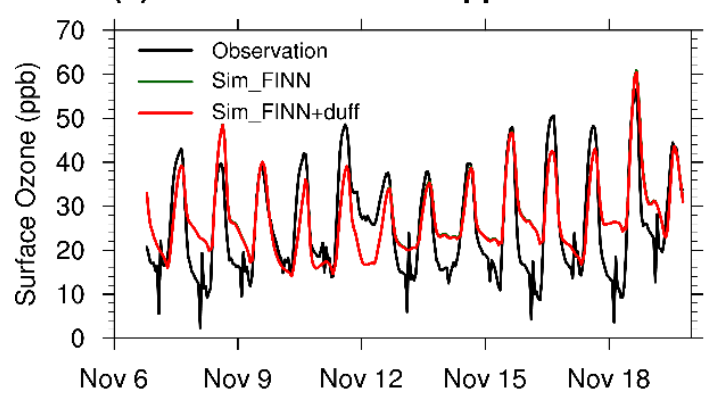

(c)

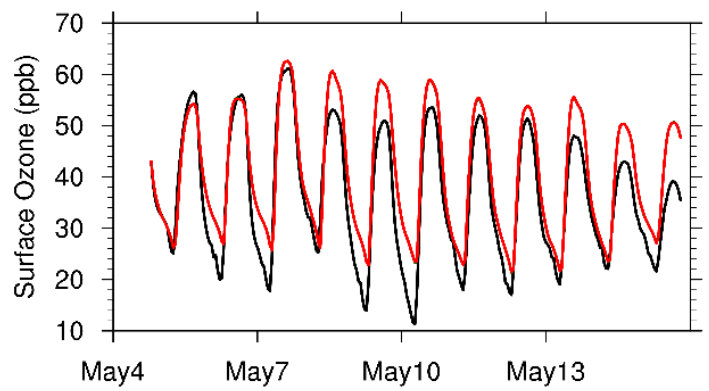

(b) 2007 Okefenokee

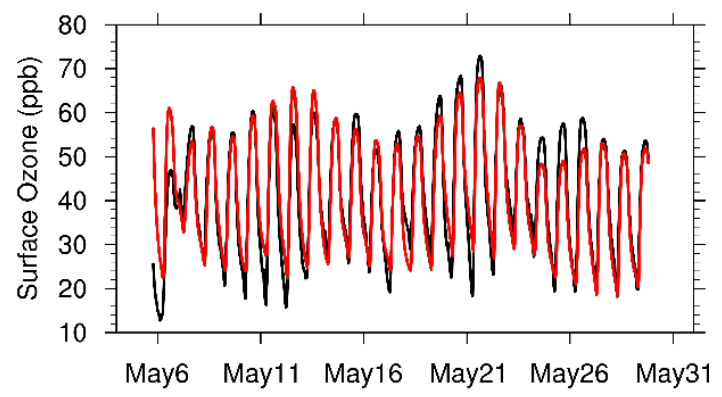

(d) 2017 Okefenokee

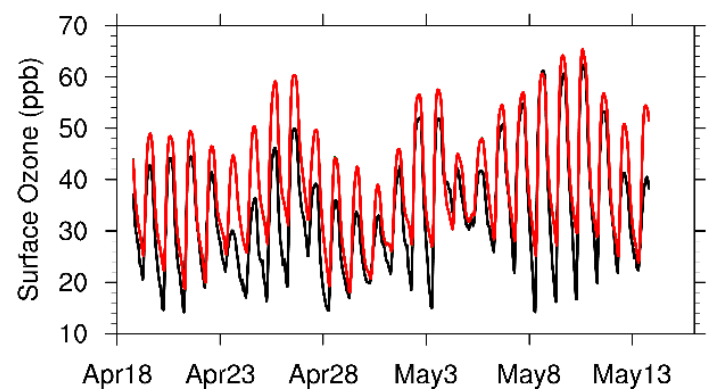


Figure 4. The time series of hourly surface ozone concentrations. Black: Measurements averaged over observation sites within the simulation domain. Green and red: Simulations of Sim_FINN and Sim_FINN+duff, respectively, averaged over the observation sites.

(a)

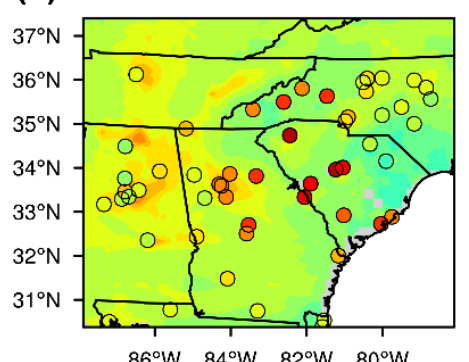

(b)

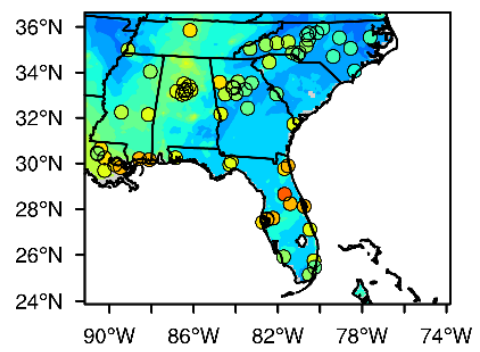

(c)

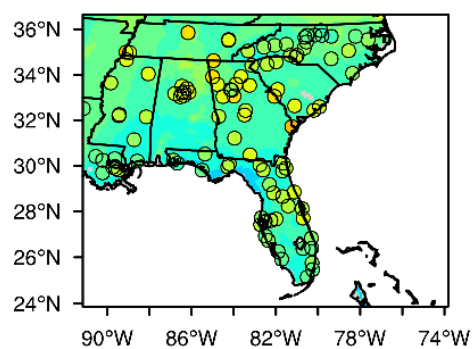

(d)

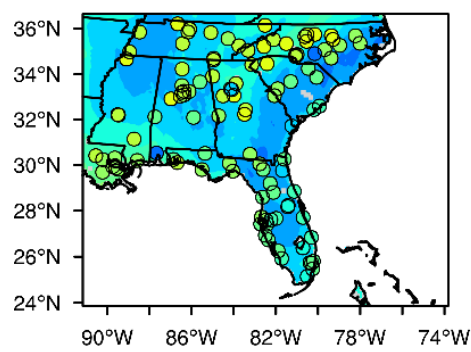

(e)

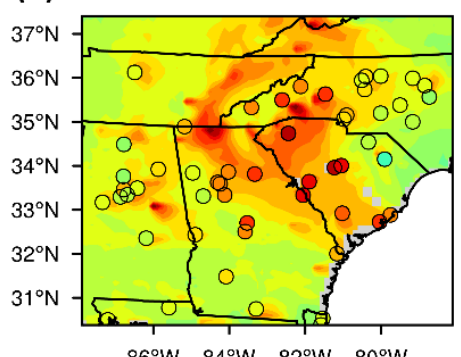

(f)

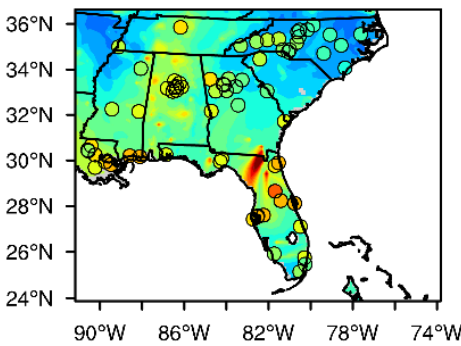

(g)

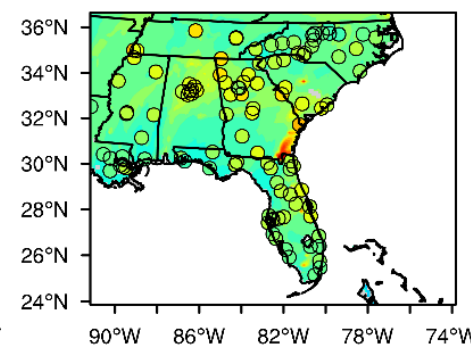

(h)

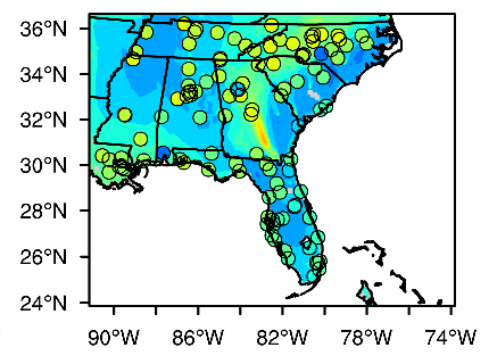

(i)

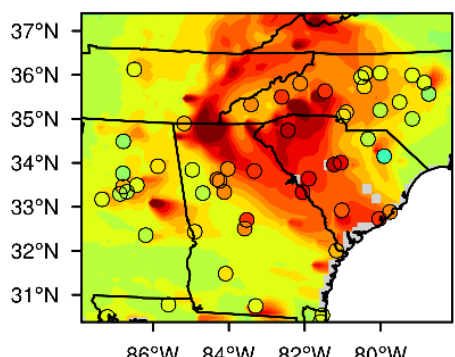

(j)

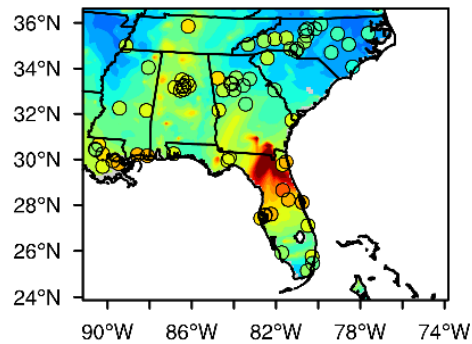

(k)

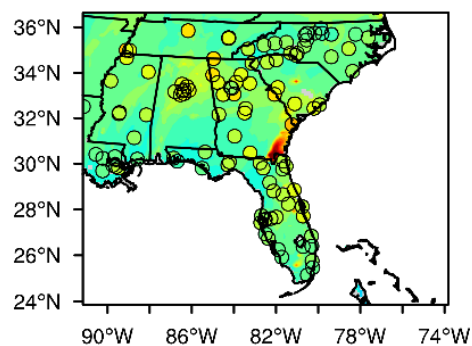

(I)

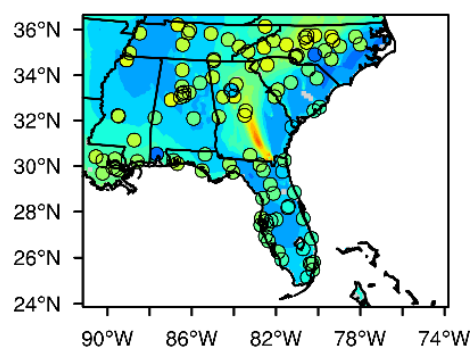

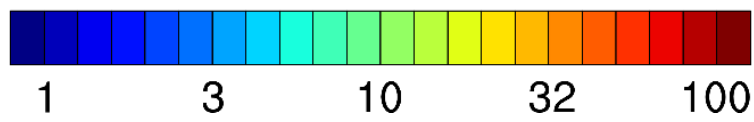


Figure 5. The mean surface concentration of simulated and observed $\mathrm{PM}_{2.5}\left(\mu \mathrm{g} \mathrm{m}^{-3}\right)$ on representative days. (a) App16 (November 15, 2016), (b) Oke07 (May 10, 2007), (c) Oke11 (May 8, 2011), and (d) Oke17 (April 29, 2017) for sim_nofire. (e) - (h) are the corresponding fire cases for sim_FINN, and (i) - (l) are the corresponding fire cases for sim_FINN+duff. The color scatters represent the observed daily mean $\mathbf{P M}_{2.5}$ concentrations.

(a)

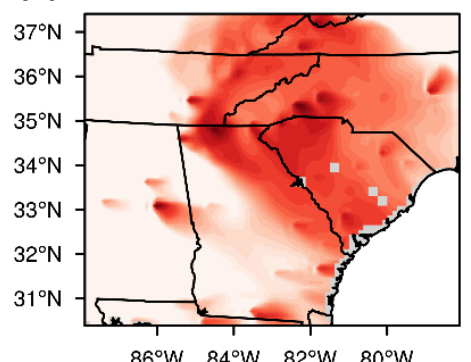

(b)

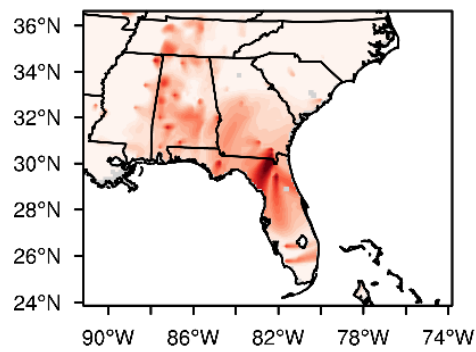

(c)

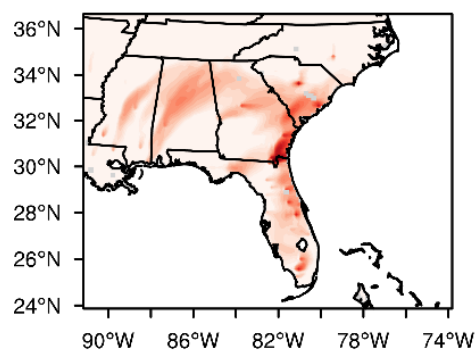

(d)

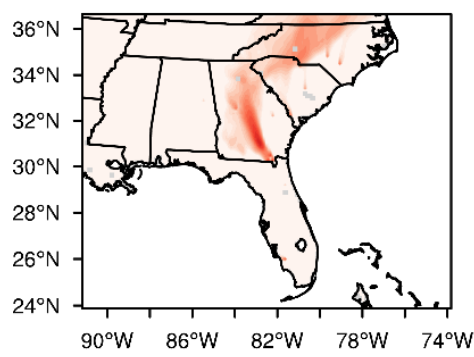

(e)

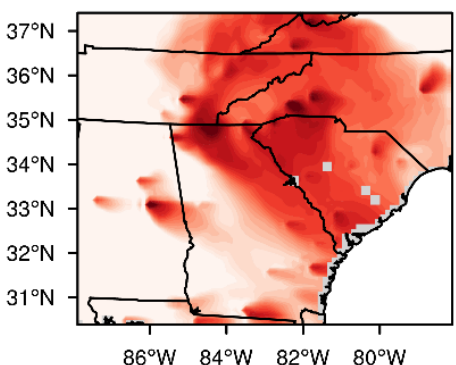

(f)

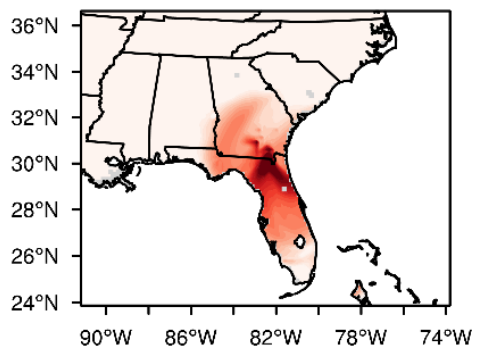

(g)

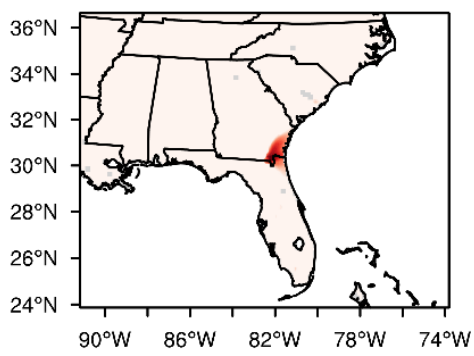

(h)

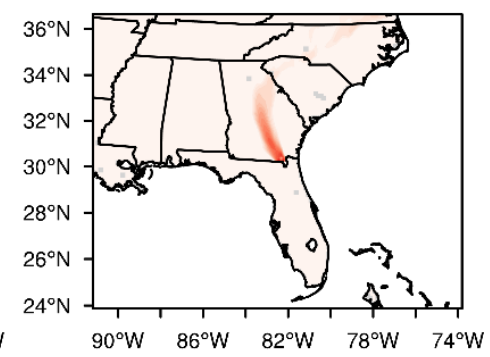

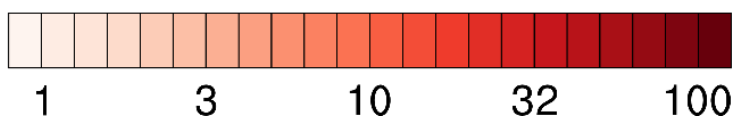


Figure 6. The surface $\mathrm{PM}_{2.5}$ concentration change $\left(\mu \mathrm{g} \mathrm{m}^{-3}\right)$ on representative days. (a) The change due to above-ground fuel burning during App16 (November 15, 2016), (b) Oke07 (May 10, 2007), (c) Oke11 (May 8, 2011), and (d) Oke17 (April 29, 2017 ). (e) - (h) are the corresponding changes due to duff burning.

(a)

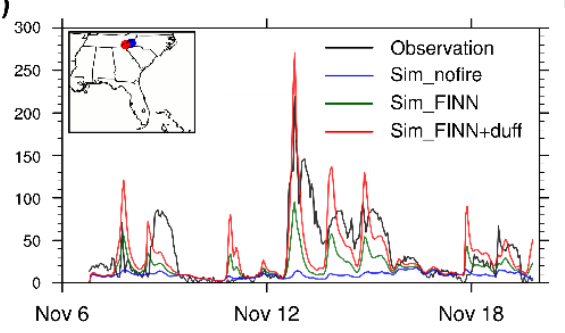

(d)

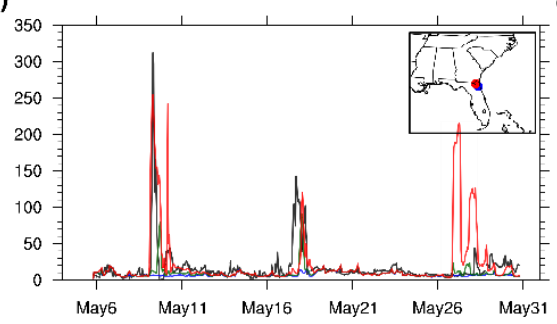

(g)

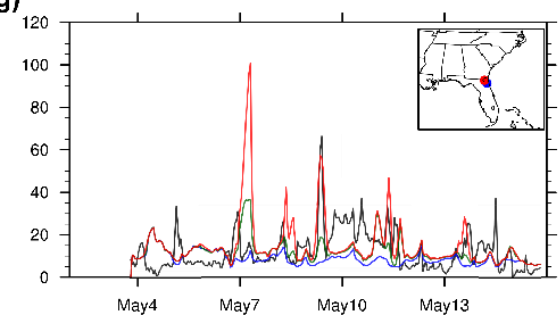

(b)

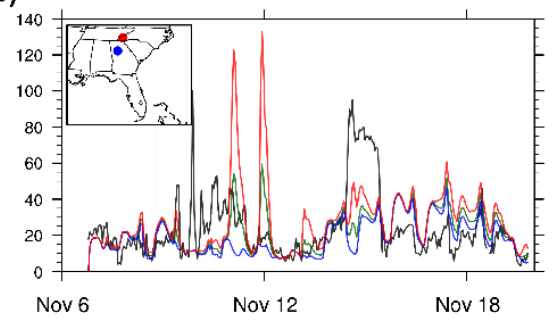

(e)

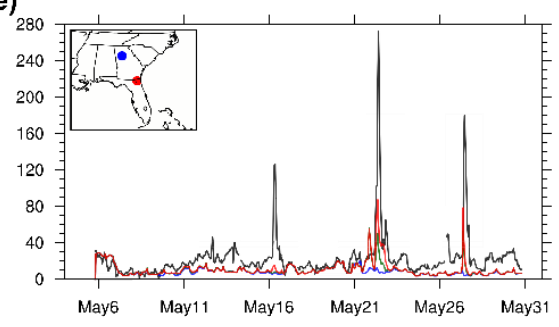

(c)

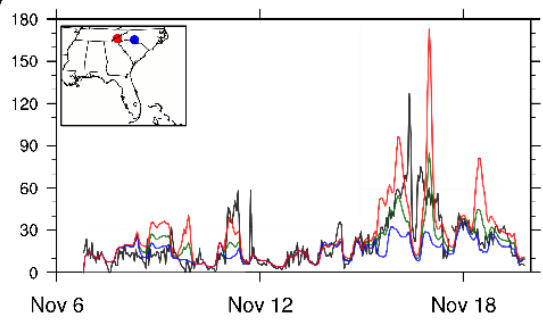

(f)

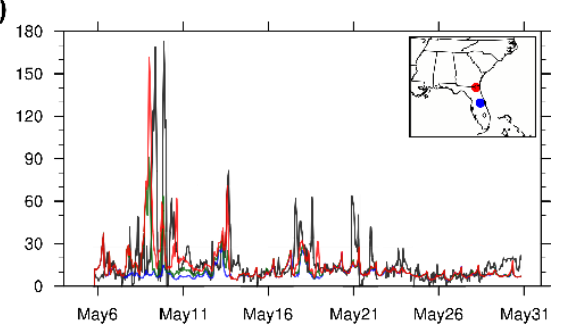

(h)

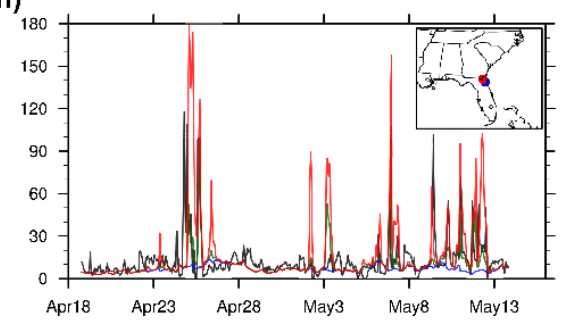

Figure 7. Comparisons of in-situ hourly surface PM2.5 concentrations $\left(\mu \mathrm{g} \mathrm{m}^{-3}\right.$ ) among the observation (black), sim_nofire (blue), sim_FINN (green) and sim_FINN+duff (red) simulations. (a - c) App16, (d - f) Oke07, (g) Oke11 and (h) the 2017 Okefenekee Fire. The fire location (red) and site location (blue) are shown in the map attached to each panel. The observation sites are located in (a) Macon county, NC, (b) Fulton county, Georgia, (c) Mecklenburg county, NC, (d) Duval county, Florida, (e) Fulton county, Georgia, (f) Orange county, Florida, (g) - (h) Duval county, Florida. 
(a)

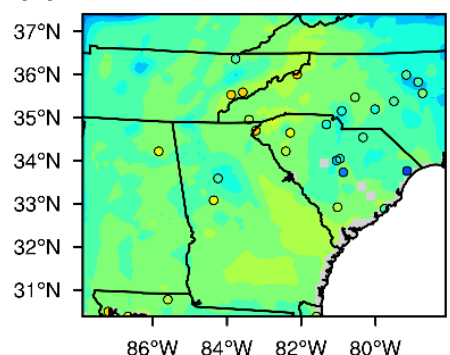

(b)

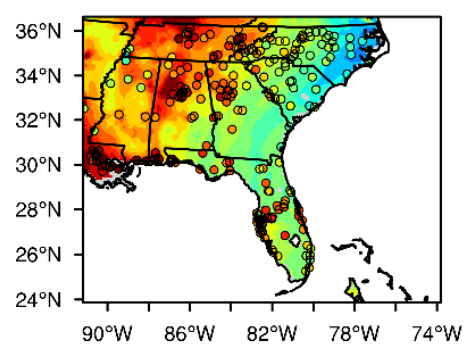

(c)

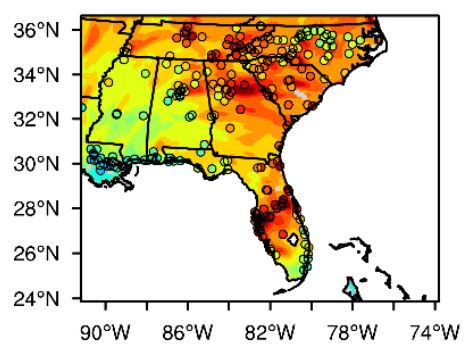

(d)

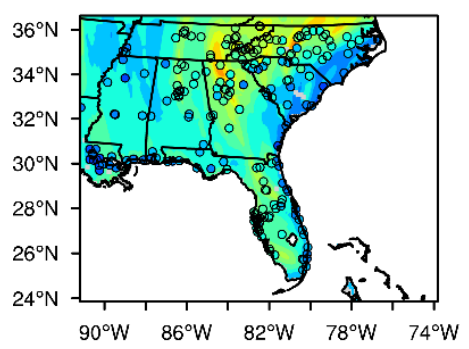

(e)

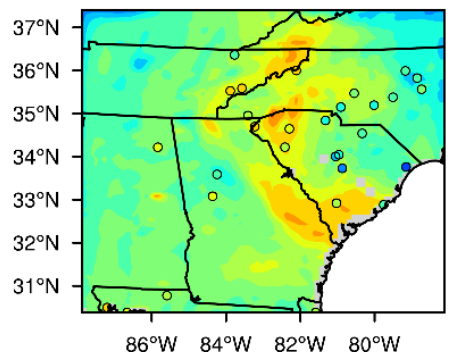

(f)

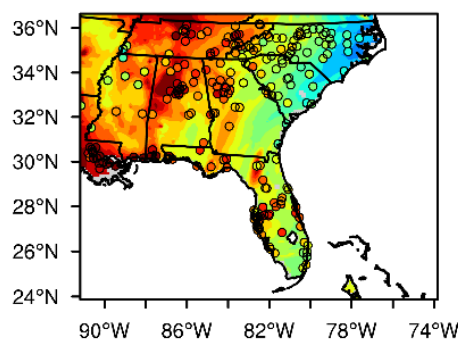

(g)

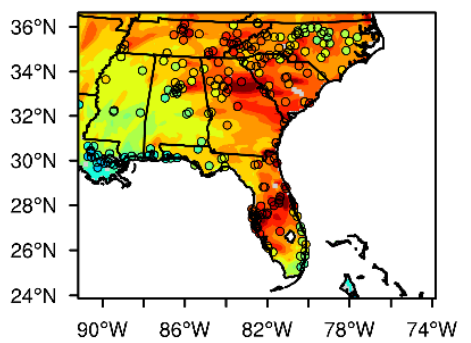

(h)

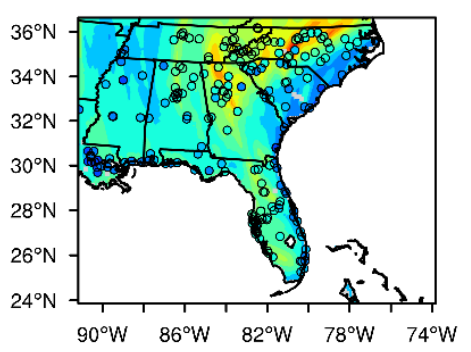

(i)

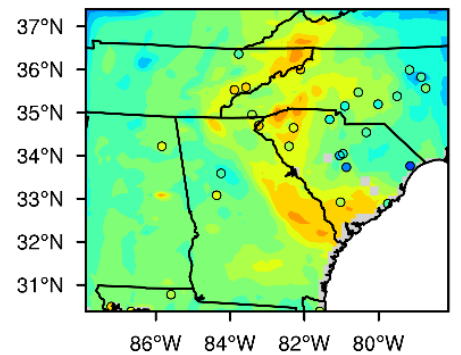

(j)

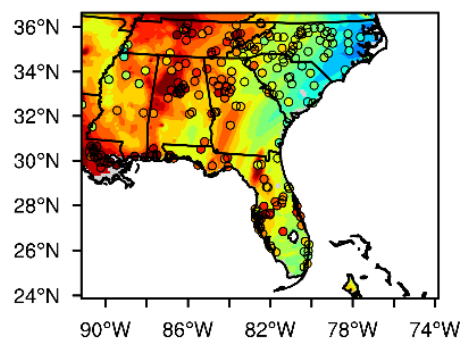

(k)

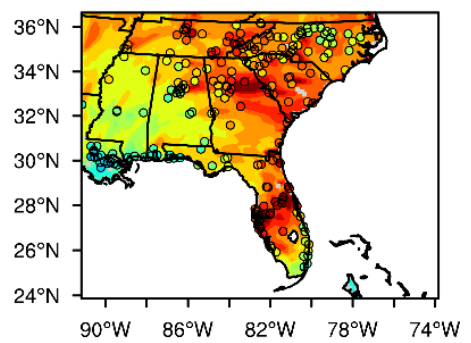

(I)

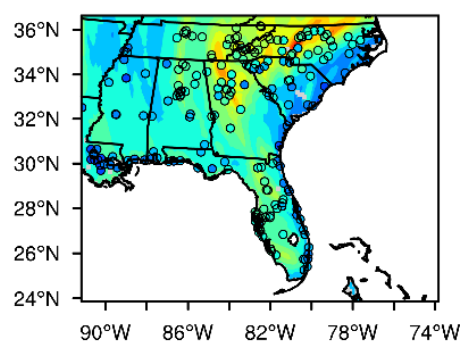

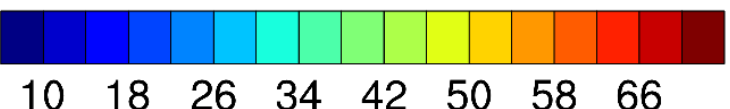

Figure 8. The day-time mean (from local time $10 \mathrm{am}$ to $6 \mathrm{pm}$ ) surface ozone concentration of simulated and observed ozone (ppb) on representative days. (a) App16 (November 15, 2016), (b) Oke07 (May 10, 2007), (c) Oke11 (May 8, 2011), and (d) Oke17 (April 29, 2017) for sim_nofire. (e) - (h) are the corresponding fire cases for sim_FINN, and (i) - (l) are the corresponding fire cases for sim_FINN+duff. The color scatters represent the observed day-time mean surface ozone concentrations. 
(a)

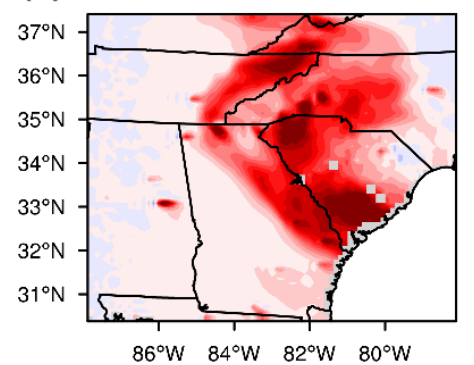

(b)

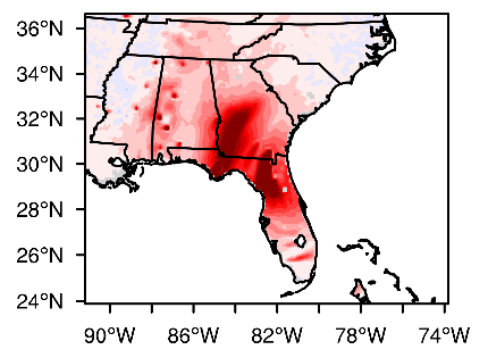

(c)

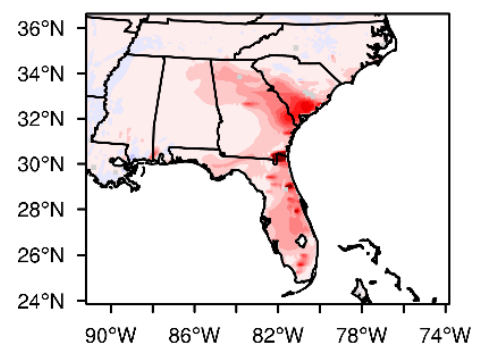

(d)

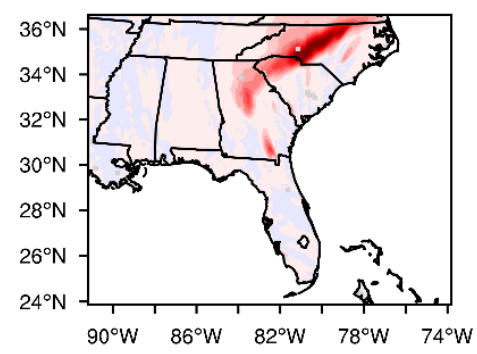

(e)

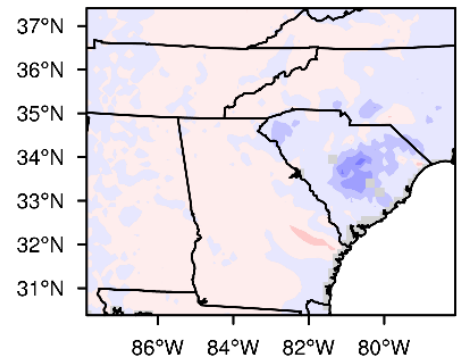

(f)

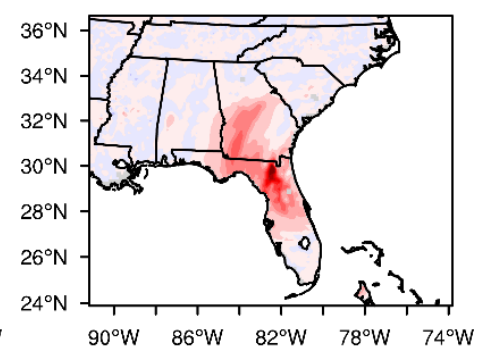

(g)

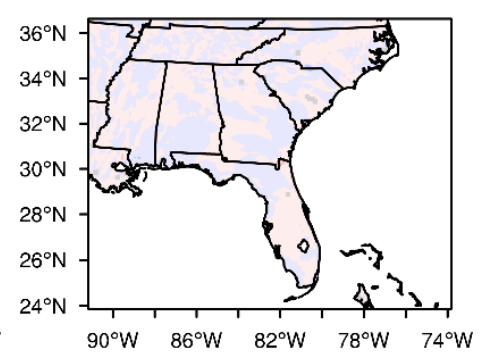

(h)

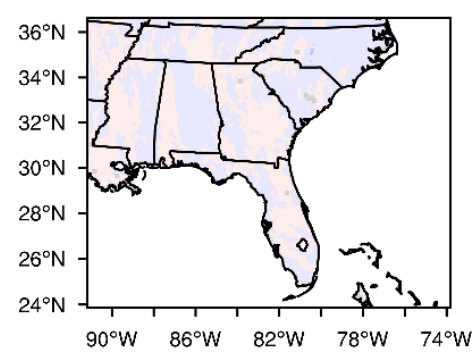

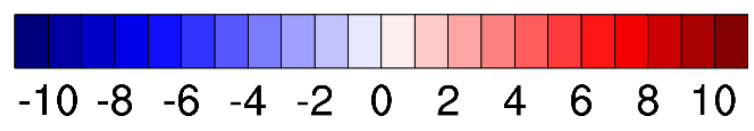

Figure 9. The day-time mean (from local time 10 am to $6 \mathrm{pm}$ ) surface ozone concentration change due to above-ground fuel burning (ppb) on representative days. (a) 2016 southern Appalachian case (November 15, 2016), (b) Oke07 (May 10, 2007), (c) Oke11 (May 8, 2011), and (d) Oke17 (April 29, 2017). (e) - (h) are the corresponding changes due to duff burning. 
(a)

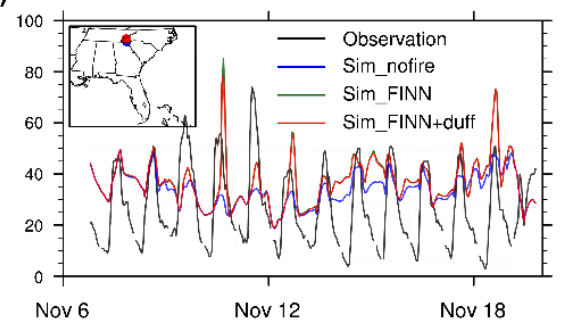

(d)

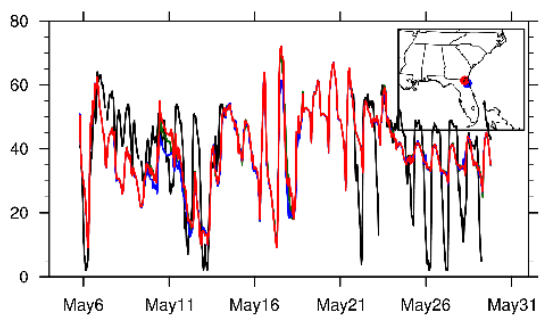

(b)

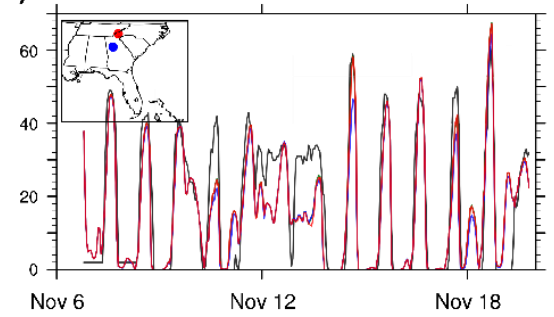

(e)

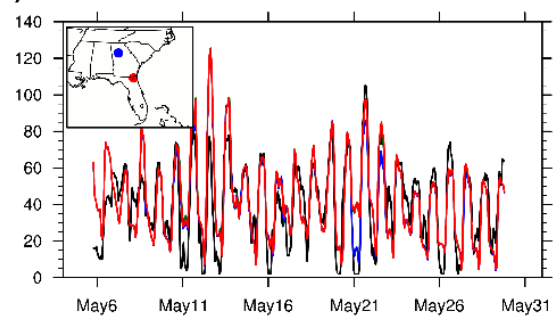

(c)

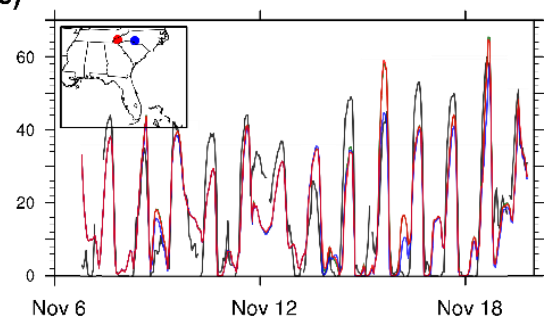

(f)

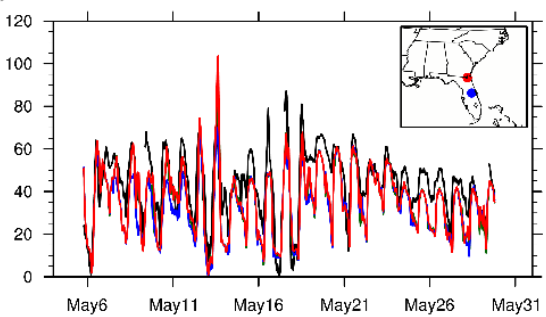

(g)

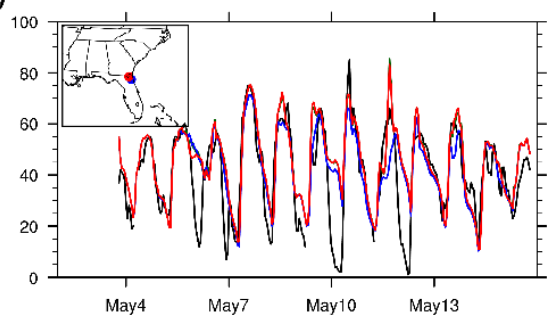

(h)

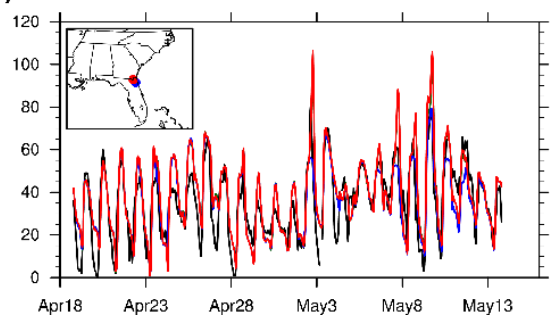

Figure 10. Comparisons of in-situ hourly surface ozone concentrations (ppb) among the observation (black), sim_nofire (blue), sim_FINN (green) and sim_FINN+duff (red) simulations. (a - c) App16, (d - f) Oke07, (g) Oke11 and (h) Oke17. The fire location (red) and site location (blue) are shown in the map attached to each panel. The studied sites are in (a) Macon county, North Carolina, (b) Fulton county, Georgia, (c) Mecklenburg county, NC, (d) Duval county, Florida, (e) Fulton county, Georgia, (f) Orange county, Florida, (g) - (h) Duval county, Florida. 
Table 1 Simulations and experiments.

\begin{tabular}{|c|c|c|c|}
\hline \multirow{2}{*}{$\begin{array}{c}\text { Simulation and } \\
\text { experiment }\end{array}$} & \multirow{2}{*}{ Simulation Period } & \multicolumn{2}{|c|}{ Fire emission } \\
\hline & & FINN fire emission & Duff emission \\
\hline sim_nofire & \multirow{3}{*}{$\begin{array}{c}\text { App 16: 11/7-11/22, 2016, } \\
\text { Oke07: 5/6-5/30, 2007, } \\
\text { Oke11: 5/4-5/15, 2011, } \\
\text { Ofe17: 4/19-5/13, 2017 }\end{array}$} & No & No \\
\hline sim_FINN & & 1x FINN emission & No \\
\hline sim_FINN+Duff & & 1x FINN emission & $1 \mathrm{x}$ duff emission \\
\hline exp_FINN & Oke07: May 6-16, 2007 & 2x FINN emission & $1 \mathrm{x}$ duff emission \\
\hline \multirow{2}{*}{ exp_duff } & \multirow{2}{*}{$\begin{array}{l}\text { App16: Nov 7-14, 2016, Oke07: } \\
\text { May 6-16, } 2007\end{array}$} & \multirow{2}{*}{ 1x FINN emission } & $0.8 \mathrm{x}$ duff emission \\
\hline & & & 1.2x duff emission \\
\hline
\end{tabular}

Table 2. Comparison of duff and temperate mixed forest emission factors $(\mathrm{g} / \mathrm{kg})$ used in this study.

\begin{tabular}{|c|c|c|}
\hline Species & Peat and duff & $\begin{array}{c}\text { FINN temperate } \\
\text { mixed forest }\end{array}$ \\
\hline $\mathrm{CO}$ & $271 \pm 51^{\mathrm{a}}$ & $102^{\mathrm{e}}$ \\
\hline $\mathrm{NO}$ & $0.559^{\mathrm{b}}$ & $0.34^{\mathrm{e}}$ \\
\hline $\mathrm{NO}_{2}$ & $0.176^{\mathrm{b}}$ & $2.7^{\mathrm{e}}$ \\
\hline $\mathrm{SO}_{2}$ & $1.76^{\mathrm{b}}$ & $1^{\mathrm{f}}$ \\
\hline $\mathrm{NH}_{3}$ & $2.67^{\mathrm{b}}$ & $1.5^{\mathrm{e}}$ \\
\hline $\mathrm{PM}_{2.5}$ & $50 \pm 16^{\mathrm{c}}$ & $13^{\mathrm{f}}$ \\
\hline $\mathrm{OC}$ & $37.5^{\mathrm{d}}$ & $9.2^{\mathrm{f}}$ \\
\hline $\mathrm{BC}$ & $0.375^{\mathrm{d}}$ & $0.56^{\mathrm{f}}$ \\
\hline
\end{tabular}

${ }^{a}$ Urbanski 2014, averaged based on Geron and Hays (2013) and Hao et al. (2007).

b Yokelson et al. (2013)

c Urbanski 2014, an average of Geron and Hays (2013)

d An estimated 100:1 ratio of OC/BC emission factors based on Jen et al. (2019), after applying the PM2.5/carbonaceous aerosol emission ratio from the FINN emission factors.

e Akagi et al. (2011)

${ }^{\mathrm{f}}$ Andreae (2008) in extratropical Forest 
Table 3. Summary of the increased ratio of $\mathrm{PM}_{2.5}$ and ozone due to duff burning and above-ground fuel burning. The bold numbers represent that the increase or decrease ratio passes the Student's t-test with $\mathbf{p}=\mathbf{0 . 0 5}$.

\begin{tabular}{|c|c|c|c||c|c|}
\hline Year & Location & $\begin{array}{c}\text { fire-nofire } \\
\mathrm{PM}_{2.5}\end{array}$ & $\begin{array}{c}\text { duff-noduff } \\
\mathrm{PM}_{2.5}\end{array}$ & $\begin{array}{c}\text { fire-nofire } \\
\text { ozone }\end{array}$ & $\begin{array}{c}\text { duff-noduff } \\
\text { ozone }\end{array}$ \\
\hline 2007 & Fire region & $\mathbf{6 3 . 4 0 \%}$ & $\mathbf{1 3 1 . 9 0 \%}$ & $\mathbf{3 . 3 0 \%}$ & $0.90 \%$ \\
\hline 2007 & Atlanta & $\mathbf{1 3 . 2 0 \%}$ & $\mathbf{6 . 0 0 \%}$ & $2.10 \%$ & $-0.10 \%$ \\
\hline 2007 & Charlotte & $7.20 \%$ & $2.60 \%$ & $1.40 \%$ & $-0.10 \%$ \\
\hline 2007 & Orlando & $\mathbf{2 8 . 3 0 \%}$ & $\mathbf{1 7 . 7 0 \%}$ & $9.10 \%$ & $2.90 \%$ \\
\hline 2007 & Miami & $\mathbf{2 7 . 2 0 \%}$ & $\mathbf{2 4 . 8 0 \%}$ & $\mathbf{7 . 0 0 \%}$ & $1.90 \%$ \\
\hline 2007 & New Orleans & $\mathbf{9 . 8 0 \%}$ & $\mathbf{8 . 5 0 \%}$ & $4.10 \%$ & $2.20 \%$ \\
\hline 2016 & Fire region & $\mathbf{8 0 . 6 0 \%}$ & $\mathbf{6 1 . 3 0 \%}$ & $\mathbf{5 . 2 0 \%}$ & $-0.20 \%$ \\
\hline 2016 & Atlanta & $\mathbf{2 8 . 1 0 \%}$ & $\mathbf{2 1 . 3 0 \%}$ & $10.70 \%$ & $2.50 \%$ \\
\hline 2016 & Charlotte & $\mathbf{4 1 . 2 0 \%}$ & $\mathbf{2 9 . 7 0 \%}$ & $22.50 \%$ & $4.90 \%$ \\
\hline 2011 & Fire region & $\mathbf{4 1 . 7 0 \%}$ & $\mathbf{1 3 . 0 0 \%}$ & $\mathbf{4 . 8 0 \%}$ & $0.20 \%$ \\
\hline 2017 & Fire region & $\mathbf{2 9 . 7 0 \%}$ & $\mathbf{1 0 . 9 0 \%}$ & $2.70 \%$ & $0.00 \%$ \\
\hline
\end{tabular}

*The "fire region" is the squared $6^{\circ} \times 6^{\circ}$ area with the fire site in the center. 